\title{
Upogebiidae (Decapoda: Thalassinidea) mostly from the Dampier Archipelago, Western Australia
}

\author{
Nguyen Ngoc-Ho \\ Muséum national d'Histoire naturelle, Département Milieux et Peuplements aquatiques \\ 61, rue Buffon, Case postale 5 F - 75231 Paris Cedex 05 France. \\ Email: nngoc-houmnh.fr
}

\begin{abstract}
Nine species of Upogebiidae from the Dampier Archipelago, Western Australia, one of which is new to science, are studied in this work: Gebiacantha dampieri sp. nov., G. priochela Sakai, 1993, Upogebia australiensis de Man, 1927, U. balmaorum Ngoc-Ho, 1990, U. barbata (Strahi, 1862), U. carinicauda (Stimpson, 1860), U. darwinii (Miers, 1884), U. fallax de Man, 1905, and $U$. holthuisi Sakai, 1982. They are compared with close relatives from the Indo-Pacific that include: $U$. bowerbankii (Miers, 1884), $U$. tractabilis (Hale, 1941), U. ancylodactyla (de Man, 1905), U. intermedia (de Man, 1888), resurrected as a valid species, and $U$. saintlaurentae sp. nov. An identification key is presented.
\end{abstract}

\section{INTRODUCTION}

Nine species of Upogebiidae, one of which is new to science, recently collected from the Dampier Archipelago are reported in this work. The species represented are: Gebiacantha dampieri sp. nov., $G$. priochela Sakai, 1993, Upogebia australiensis de Man, 1927, U. balmaorum Ngoc-Ho, 1990, U. barbata (Strahl, 1862), U. carinicauda (Stimpson, 1860), U. darwinii (Miers, 1884), U. fallax de Man, 1905, and U. holthuisi Sakai, 1982. Three of these, i.e. U. balmaorum, $U$. holthuisi, U. fallax, nevertheless, include only a single specimen each and the identification of the first two is provisional.

Except for the new taxon, all species are previously known from the Indo-Pacific, but variations exist in the Dampier fauna. The Dampier material is described, illustrated and compared with close relatives that include: $U$. bowerbankii (Miers, 1884), U. tractabilis (Hale, 1941), U. ancylodactyla (de Man, 1905), U. intermedia (de Man, 1888), resurrected as a valid species, and $U$. saintlaurentae sp. nov. The opportunity has been taken to study these species and include them in a key.

\section{MATERIALS AND METHODS}

The material studied belongs to the collections of the Muséum national d'Histoire naturelle, Paris (NMHN), the National Museum of Victoria, Melbourne (NMV), the Western Australian Museum, Perth (WAM), and the Zoologisch Museum, Amsterdam (ZM.A).

The measurements given in the description are: carapace length (cl), given for all specimens, measured from the tip of the rostrum to the posterior border of the carapace; total length. (tl), given for types or figured specimens, measured from the tip of the rostrum to the posterior border of the telson. Abbreviations are as follows: juv. for juvenile, juvs for juveniles, ovig. for ovigerous

Figured specimens and appendages were stained with a weak solution of chlorazol black. If not otherwise stated, the anterior part of the carapace is figured in dorsal and lateral view respectively, the telson and uropods are figured in dorsal view and appendages in lateral view.

\section{Infraorder THALASSINIDEA Latreille, 1831}

\section{Superfamily Callianassoidea Dana, 1852}

\section{Family Upogebiidae Borradaile, 1903}

\section{Remarks}

Morphological characters of the rostrum, carapace, appendages, the first pereopods, and especially the telson and uropods, are usually considered in the identification of upogebiid species. The shape of the telson in the literature, however, especially its length / width ratio, could be inaccurate if the segment is not laid flat for drawing.

In the present work, characters of the second pereopod, its propodus and dactylus, are also used although they do not vary specifically, which means that many species may have the same pereopod 2 morphology. All known Gebiacantha species, for example, have a similar pereopod 2 with an approximately rectangular propodus and a slender 
dactylus. Yet pereopod 2 can be informative and specimens of the same species are likely to share the same morphology of pereopod 2, while specimens with different shapes of pereopod 2 are likely to belong to different species.

Characters of the mandible, epipods and arthrobranchs of the Upogebiidae were figured and discussed by Ngoc-Ho (1981: 244, figs 11, 12). The arthrobranchs were divided into type $\mathrm{A}$ with a fairly large and flattened structure on either side of the rachis (Ngoc-Ho, 1981, fig. 12A), type B with a narrower tubular structure on either side of the rachis (Ngoc-Ho, 1981, fig. 12B) and type $\mathrm{C}$ with two tubular structures on either side of the rachis (Ngoc-Ho, 1981, fig. 12C). However, it is sometimes hard to differentiate the A type from the B type, and the width of the structures seems to be related to the size of the specimens. In this work, only the number of structures on either side of the rachis (one or two) is indicated.

The linea thalassinica, as a taxonomic character in the Thalassinidea, was discussed by Poore (1994: 82). In the Upogebiidae, it is depressed anteriorly and in most, if not all, species, it is present anterior to the cervical groove. It varies after crossing the groove and reaches the posterior margin of the carapace in certain species, but does not in others. In the latter, however, as Poore noted (1994: 83), an oblique ridge on the branchial flap may appear with an associated groove in place of the posterior section of the linea thalassinica. On the other hand, within the same species, the linea thalassinica can be faint and hardly visible in small specimens, or those with a thin carapace: In Upogebia tractabilis, for example, it is apparently absent from the holotype and other small specimens from Gulf St. Vincent, South Australia, of tl 15-21 mm, examined by Sakai (1982: 17) and Ngoc-Ho (1994: 74). It is present in the material from Cottesloe, Western Australia, comprising larger specimens with a better calcified carapace, but is faint in a few of them. The linea thalassinica and its variations are indicated in this work but not treated as important as treated by Sakai (1982).

\section{Key to species of Upogebiidae from the Dampier Archipelago and close relatives treated in this work}

1 Infrarostral spines present ............ Gebiacanth 2

Infrarostral spines absent .................. Upogebia 3

2 One infrarostral spine, third and fourth article of antennal peduncle with one and two lower spines respectively ...... Gebiacantha dampieri

Two or three infrarostral spines, third and fourth article of antennal peduncle with two and three lower spines respectively

Gebiacantha priochela
3 More than four rostral teeth ............................... 4

Four rostral teeth …........................................... 8

4 Rostrum about as long as wide at base ............. 5

Rostrum over one and a half times as long as wide at base. Sixth abdominal somite and uropods over twice as long as telson

Upogebia fallax

5 Pereopod 1 with large teeth on cutting edge of fixed finger; propodus with two mesial distal spines near base of dactylus

Pereopod 1 with no large teeth on cutting edge of fixed finger; no mesial distal spines near base of dactylus

6 Antennular exopod usually longer than endopod. Pereopod 1 merus unarmed; propodus unarmed, small mesial distal spines near base of dactylus

Upogebia australiensis

Antennular exopod about as long as endopod. Pereopod 1 merus with spinules or tubercles; propodus with lower proximal and numerous mesial upper tubercles, large mesial distal spines near base of dactylus ......

Upogebia bowerbanki

7 Pereopod 1 fixed finger with dentate cutting edge; pereopod 2 propodus longer than dactylus; telson subquadrate, posterolateral angle not rounded; maxilliped 2 with upright epipod. ............................ Upogebia tractabilis

Pereopod 1 fixed finger with unarmed cutting edge; pereopod 2 propodus about as long as dactylus; telson broader than long, posterolateral angle rounded; maxilliped 2 with folded epipod .... Upogebia balmaorum

8 Anterolateral border of carapace with spine, peropod 1 subchelate, propodus with large lower mesial spine posterior to fixed finger 9

Anterolateral border of carapace unarmed, pereopod 1 chelate, no mesial lower spine on propodus 10

9 Rostrum slightly overreaching eyestalks. Pereopod 1 fixed finger and dactylus with weakly dentate cutting edge. Eggs numerous and small ..................... Upogebia carinicauda

Rostrum far overreaching eyestalks, with parallel lateral borders. Pereopod 1 fixed finger and dactylus with round teeth on cutting edge, large mesial proximal one on dactylus. Eggs few and large ....

Upogebia saintlaurentae

10 All four rostral spines subdistal or distal, rostrum truncate distally

Two distal rostral spines, two subdistal, rostrum slightly tapering distally ................ 12 
11 Rostral spines subdistal; antennal scale membranous or absent. Pereopod 1 merus with lower spinules, no lower distal spine on carpus, fixed finger and dactylus straight, unarmed. Telson slightly broader than long, slightly broader distally than proximally ....

Upogebia barbata

Rostral spines distal. Pereopod 1 merus with lower spines or spinules, small or large upper and lower distal spine on carpus, fixed finger with small teeth or denticles on cutting edge: dactylus with no proximal round tooth on cutting edge, with curved or often strongly curved tip. Telson subquadrate or slightly broader than long .... Upogebia ancylodactyla

Rostral spines distal. Pereopod 1 merus with lower tubercles, granules or unarmed; no or small lower distal spine on carpus; fixed finger with dentate cutting edge, dactylus cutting edge with large mesial round tooth proximally. Posterior border of sixth abdominal somite often dentate; telson broader than long ............. Upogebia darwinii

12 Pereopod 1 merus with numerous spinules on whole lower border, large upper and lower distal spine on carpus, cutting edge of fixed finger dentate, that of dactylus with large mesial round tooth proximally. Posterior border of sixth abdominal somite unarmed; telson approximately one and a half times as broad as long ................ Upogebia intermedia

Pereopod 1 merus unarmed or with lower tubercles; no lower distal spine on carpus; fixed finger with dentate cutting edge, dactylus unarmed. Posterior border of sixth abdominal somite unarmed; telson subquadrate or slightly broader than long..... Upogebia holthuisi

\section{Genus Gebiacantha Ngoc-Ho, 1989}

\section{Gebiacantha dampierisp. nov.} Figures 1, 2A-C

\section{Material examined}

\section{Holotype}

Western Australia, Dampier Archipelago. WAM C 39096 (male, d $5 \mathrm{~mm}, \mathrm{tl} 13 \mathrm{~mm}$ [figured], $4.4 \mathrm{~km}$ $\mathrm{N}$ of $\mathrm{W}$ end of Kendrew I, mud and shells, $38 \mathrm{~m}$, coll. G.C.B Poore and R.A King, 25.07.1999.

\section{Paratypes}

WAM C 39097 (1 male, cl $5.0 \mathrm{~mm}, \mathrm{tl} 12.5 \mathrm{~mm}$ [figured], 2 males of $5.0-5.5 \mathrm{~mm}, \mathrm{t} 13-13.5 \mathrm{~mm}, 1$ female, cl $5.5 \mathrm{~mm}, \mathrm{tl} 14.0 \mathrm{~mm}), 4.4 \mathrm{~km} \mathrm{~N}$ of $W$ end of Kendrew I, mud and shells, $38 \mathrm{~m}$; NMV I
52363 (1 male, ol $4.0 \mathrm{~mm}, \mathrm{tl} 10.5 \mathrm{~mm}$ |figured), 2 juv., ol 2.5-3.0 mm, tl $6.0-7.0 \mathrm{~mm}), 7.8 \mathrm{~km} \mathrm{NW}$ of C. Legendre (Legendre I.), muddy sand, some shell, $43 \mathrm{~m}$, coll. G.C.B. Poore and R.A. King, 14.07.1999; NMV J 52368 (1 male, cl $5.0 \mathrm{~mm}$, $\mathrm{tl}$ $12.5 \mathrm{~mm}), 12.2 \mathrm{~km} \mathrm{E}$ of C. Legendre (Legendre I.), coarse sand, $37 \mathrm{~m}$, coll. G.C.B. Poore and R.A. King, 15.07.1999.

\section{Other material examined}

Western Australia, Dampier Archipelago. WAM C 29441, (1 male: cl $4.0 \mathrm{~mm}$ ), Mermaid Sound, $-3 \mathrm{~km}$ NW of Cohen I., muddy sand, 32.0$35.0 \mathrm{~m}$, coll. M. Hewitt, 14.07.1999; NMV J 52364 (1 juv., $\mathrm{cl} 3.5 \mathrm{~mm}$ ), $4.8 \mathrm{~km}$ WNW of $W$ end of Kendrew I., shelly mud, $38 \mathrm{~m}$, coll. G.C.B. Poore and R.A. King, 25.07.1999; NMV J 523657 (1 juv, cl $2.5 \mathrm{~mm}$, tl $7.5 \mathrm{~mm}), 6 \mathrm{~km} \mathrm{NE}$ of Nelson Rocks, muddy fine sand, coll. G.C.B. Poore and R.A. King; NMV J 52366 (2 males, 1 female, 4 juvs, cl 3.0-3.5 $\mathrm{mm}, 2$ specs without carapace), $1.3 \mathrm{~km}$ off the NE tip of Enderby I., shelly mud, $17 \mathrm{~m}$, coll. G.C.B. Poore and R.A. King, 27.07.1999; NMV J 52367 (1 male, cl $3.5 \mathrm{~mm}), 10.75 \mathrm{~km}$ WNW of NW tip of Goodwyn I., sandy mud, $34 \mathrm{~m}$, coll. G.C.B. Poore and R.A. King, 21.07.1999; NMV J 52369 (1 juv., cl $2.0 \mathrm{~mm}, \mathrm{tl} 6.5 \mathrm{~mm}), 5.2 \mathrm{~km} \mathrm{~N}$ of Nelson Rocks, muddy sand, $34 \mathrm{~m}$, coll. G.C.B. Poore and R.A. King, 17.07.1999; NMV J 52394 (1 male, cl 3.0 mm, tl $8.5 \mathrm{~mm}$ ), $5.2 \mathrm{~km}$ West of Gidley I. (Mermaid Sound), coarse sand, $16 \mathrm{~m}$, coll. G.C.B. Poore and R.A. King, 18.07.1999.

\section{Diagnosis}

Rostrum with five or six dorsal teeth on lateral border, one infrarostal spine; anterolateral border of carapace with two or three spinules; lateral ridge of gastric region with five or six spines or tubercles. First article of antennular peduncle with lower spine; Third article of antennal peduncle with one or two lower spines, fourth article with two spines. Pereopod I subchelate; ischium with lower spine; merus with upper subdistal spine, six or seven lower spines; carpus with lower distal spine, three large mesial distal spines and five or six spinules along upper border; propodus bearing on mesial surface three longitudinal rows of eight or nine, four and five spines respectively from upper to lower, large spine followed by smaller one near midlength of lower border; fixed finger and dactylus cutting edge unarmed; dactylus with round tubercles on upper border. Pereopod 2 merus with two upper subdistal spines and two lower proximal spines; carpus with lower distal spinule and three or four upper spines.

Pereopod 3 merus with upper distal spinule and five to seven lower spines; carpus with lower distal spine. Telson approximately quadrate; uropods longer than telson, basipod with spinule. 


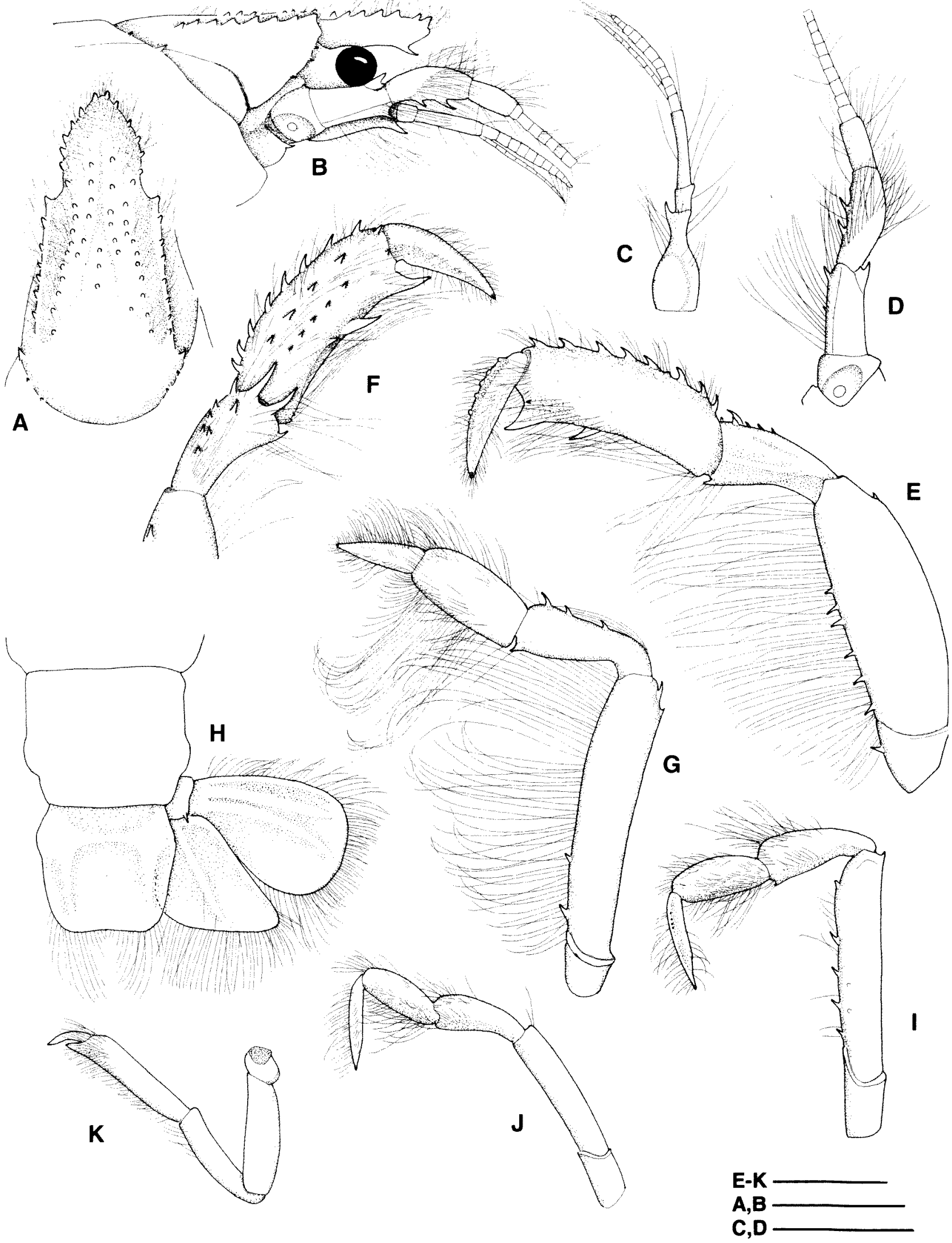

Figure 1 Gebiacantha dampieri sp. nov., A, B, E-H: holotype, male (WAM C 39096); C, D, I-K: male paratype (NMV ] 52363). A, B, anterior part of carapace; C, antennule; D antenna; E, F, pereopod 1 and distal part 1 in mesial view; G, pereopod 2; $\mathbf{H}$, telson and uropod: $\mathbf{I}, \mathbf{J}, \mathbf{K}$, pereopod 3, 4, 5, respectively. Scale: $1 \mathrm{~mm}$. 


\section{Description}

Rostrum (Figures 1A, B) approximately ovoid, projecting beyond eyes, lateral border with five or six spiniform dorsal teeth, one or (exceptionally) two infrarostral spines. Fine and faint median dorsal groove bifurcating posteriorly on either side of low longitudinal elevation bearing small rounded tubercles. Lateral groove moderately broad, lateral ridge with seven or eight spiniform spines or tubercles. Linea thalassinica extending to posterior border of carapace. Anterolateral border of carapace with three spinules. Cervical groove well defined, bearing a spinule on either side near section with linea thalassinica and two or three minute ones more dorsally. Epistome terminating dorsally in spinule. Telson approximately quadrate, lateral border convex, posterolateral angles rounded, posterior border slightly concave medially, faint inverted Ushaped carina on dorsal surface.

Antennule (Figure 1C), first peduncular article with large lower distal spine.

Antenna (Figure 1D), third peduncular article with one or two lower spines, fourth article with two spines, scale terminating in two spinules.

Pereopod 1 (Figures 1E, F) subchelate. Ischium with lower spine. Merus nearly three times as long as broad, with upper subdistal spine and six or seven lower spines. Carpus with fine longitudinal groove on upper part of external surface and faint longitudinal carina more ventrally; lower distal spine; three large mesial distal spines and five or six spinules along or near upper border. Propodus over twice as long as broad, external surface with spinule near base of fixed finger; mesial surface bearing three longitudinal rows of eight or nine, four and five spines respectively from upper to lower, one or two mesial distal spines near base of dactylus; large spine followed by smaller one near midlength of lower border; fixed finger about a third as long as dactylus, unarmed. Dactylus with corneous tip and round tubercles on upper border.

Pereopod 2 (Figure 1G) merus over five times as long as broad, two upper subdistal spines and two lower proximal spines; carpus with lower distal spinule and three or four spines along upper border; propodus approximately rectangular, over twice as long as broad; dactylus unarmed.

Pereopod 3 (Figure 11) merus about five times as long as broad, with upper distal spinule and five to seven lower spines; carpus with lower distal spine.

Pereopod 4 (Figure 1]) and pereopod 5 (Figure $1 \mathrm{~K})$ unarmed.

Uropod (Figure 1H) longer than telson, exopod with posterior border rounded, continuous with lateral external border; endopod approximately triangular, protopod with spinule.

\section{Type locality}

North Australia, Dampier Archipelago, $4.4 \mathrm{~km}$ north of the west end of Kendrew I., mud and shells, $38 \mathrm{~m}$.

\section{Etymology}

The species is named for the type locality.

\section{Remarks}

The material of Gebiacantha dampieri sp. nov. includes only young specimens, mostly males and juveniles, and one female. Gonopores are hardly visible on the coxae of the pereopod 5 in unstained males and pleopods 1 are absent from the female of tl $14 \mathrm{~mm}$.

With one exception, all specimens possess one infrarostral spine which brings them near an allied species in the area, Gebiacantha ceratophora de Man, 1905. It is questionable whether the types of the latter species (female lectotype of $\mathrm{tl} 10 \mathrm{~mm}$ and male paralectotype of $\mathrm{tl}$ $8.5 \mathrm{~mm}$, selected by de Saint Laurent and NgocHo, 1979) are young specimens of this new species. A specimen of similar size (cl $4 \mathrm{~mm}, \mathrm{tl}$ $10.5 \mathrm{~mm}$ ) is figured (Figures $2 \mathrm{~A}-\mathrm{C}$ ), for comparison with the description and figures of G. ceratophora (de Man, 1928: 69, figs 9-9g; de Saint Laurent and Ngoc-Ho, 1979: 64, figs 6-8). G. dampieri differs in:

1) a shorter rostrum (Figure $2 \mathrm{~A}$ ).

2) the antennal article 4 with two lower spines (Figure 2B) (instead of one in $G$. ceratophora).

3) the pereopod 1 with the cutting edge of the fixed finger unarmed (instead of being denticulated in G. ceratophora).

4) the telson (Figure 2C) with lateral borders more convex but the posterior border less concave medially than in $G$. ceratophora.

Gebiacantha dampieri is also related to $G$. poorei Ngoc-Ho 1994 (see Ngoc-Ho, 1994: 64, Figure 6), which is also a small species, by the morphology of the rostrum, the telson and the spinulation of the pereopods. G. poorei can be differentiated by having:

1) two large infrarostral spines.

2) five spinules on the anterolateral border of the carapace.

3) three lower spines on the antennal article 4. and 4) uropods about as long as the telson.

Gebiacantha priochela Sakai, 1993, also present in the Dampier fauna, is a larger species with specimens reaching a $\mathrm{tl}$. of $31-38 \mathrm{~mm}$. Yet certain similarities exist between its young specimens with $G$. dampieri; they are compared below.

Gebiacantha priochela Sakai, 1993 Figures $2 \mathrm{D}-\mathrm{G}$

Gebiacantha priochela Sakai, 1993: 100-105, figs 79. - Ngoc-Ho, 1994: 66, figs 7, 8 . 


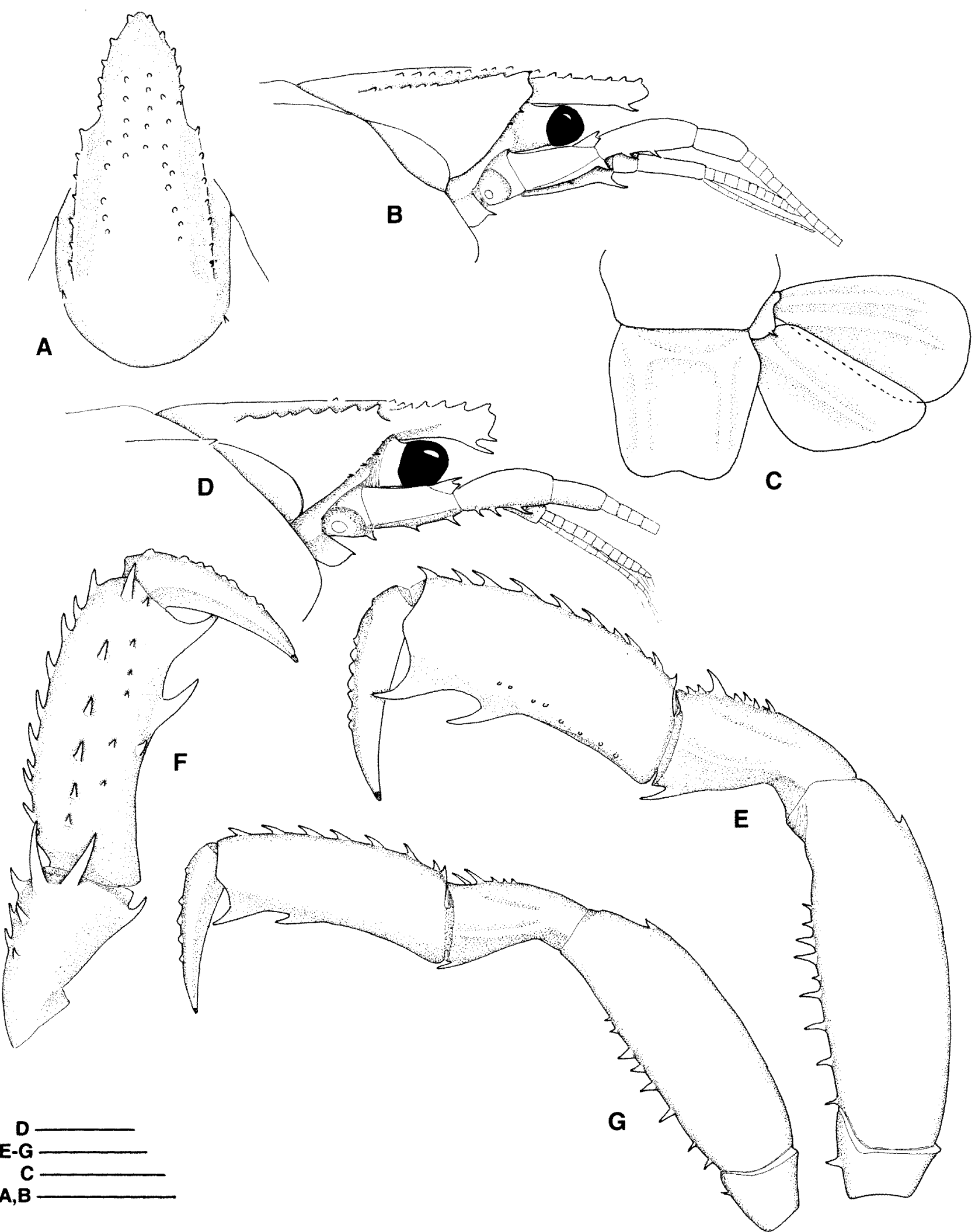

Figure 2 Gebiacantha dampieri sp. nov., A-C, male paratype (NMV J 52363). Gebiacantha priochela Sakai, D-F, young male, G, female (NMV 52362). A, B, D, anterior part of carapace; C, telson and uropod; E, G, F, pereopod 1 and distal part in mesial view. Scale: $1 \mathrm{~mm}$.

\section{Material examined}

Western Australia, Dampier Archipelago. NMV J 52359 (7 males [stout P1], cl 11.0-13.5 mm, tl 31.0$35.0 \mathrm{~mm}$; 3 detached carapaces, $\mathrm{cl} 12.0-13.0 \mathrm{~mm} ; 3$ males [slender P1], $\mathrm{cl} 8.0-10.5 \mathrm{~mm}$ tl $21.5-29.5 \mathrm{~mm}$; 4 females [2 ovig.], $\mathrm{cl} 10.5 \mathrm{~mm}, \mathrm{tl} 29.0-30.0 \mathrm{~mm}$ ) and NMV J 52360 (1 male [stout P1] cl $11.5 \mathrm{~mm}, \mathrm{tl} 33.0$ $\mathrm{mm} ; 3$ females [2 ovig.], cl 10.0-11.0 mm, tl 28.0-30.0 
$\mathrm{mm}), 4.4 \mathrm{~km} \mathrm{~N}$ of $\mathrm{W}$ end of Kendrew I., muddy shell, $38 \mathrm{~m}$, coll. G.C.B. Poore and R.A. King, 25.07.1999; NMV J 53261 (1 male [stout P1], d 12.0 $\mathrm{mm}, \mathrm{tl} 32.0 \mathrm{~mm}), 7.8 \mathrm{~km} \mathrm{NW}$ of C. Legendre (Legendre I.), 43 m, coll. G.C.B. Poore and R.A. King, 14.07.1999; NMV J 52362 (young specimens, 9 males, cl $4.5-6.5 \mathrm{~mm}, \mathrm{tl} 10.5-17.5 \mathrm{~mm}$ [largest of $\mathrm{cl} 6.5 \mathrm{~mm}$ figured]; 1 juv., cl $4.5 \mathrm{~mm}$; 6 females, $\mathrm{cl} 4.5-5.5 \mathrm{~mm}$, tl $11.5-14.5 \mathrm{~mm}$ [largest of d $5.5 \mathrm{~mm}$ figured]), $7 \mathrm{~km}$ $\mathrm{W}$ of Roly Rock, muddy coarse sand, $32 \mathrm{~m}$, coll. G.C.B. Poore and R.A. King, 21.07.1999; WAM C 29440 (1 male [stout P1], cl $10.0 \mathrm{~mm}, \mathrm{tl} 26.0 \mathrm{~mm}$ ), Rosemary I., 39 m, M. Hewitt et al coll., 17.07.1999.

\section{Distribution}

Australia: West of Fog Bay (type locality, Sakai, 1993); North West Shelf, Queensland, Great Barrier Reef (Ngoc-Ho, 1994), Dampier Archipelago..

\section{Remarks}

The sample NMV J 52362, includes young specimens that are often provided with one or two infrarostral spines and three spines on article 4 of the antennal peduncle (Figure 2D). Female gonopores are well open on the coxae of the pereopod 3 in all females examined but pleopods 1 are present in the largest specimen only, of $\mathrm{cl} 5.5$ $\mathrm{mm}$ and $\mathrm{tl} 14.5 \mathrm{~mm}$.

In previous works by Sakai (1993) and Ngoc-Ho (1994), the material studied comprised mostly large males of tl 22-37 $\mathrm{mm}$ and 25.5-38.5 $\mathrm{mm}$ respectively. Both authors notified two forms of males differing by the morphology of the pereopods 1: in the first type, this appendage is stout with a very short fixed finger while it is slender, with a larger fixed finger in the second type. Ngoc-Ho (1994) described and depicted pereopods 1 of the first (Figures $7 c, d$ ) and the second type (Figures $8 \mathrm{e}, \mathrm{f}$ ) in males of similar sizes (28 $\mathrm{mm}$ and $28.5 \mathrm{~mm}$ ).

Males from the Dampier Archipelago provide a wider range of sizes and the morphology of their pereopod 1 is indicated above. It can be noted that, except for the specimen WAM C 29440 of $\mathrm{tl} 26 \mathrm{~mm}$, males with a stout pereopod 1 are of $t \mathrm{l} 31-35 \mathrm{~mm}$ while those with a slender pereopod 1 are all smaller, of tl $21.5-29.5 \mathrm{~mm}$; their pereopod 1 is about the same as that of the young (Figure 2E, F) and of the female (Figure 2G). If the materials studied by Sakai (1993) and Ngoc-Ho (1994) are also considered, it can be concluded that the stout male pereopod 1 with a very short fixed finger is found in large specimens, i.e. those of $\mathrm{tl}>30 \mathrm{~mm}$. The pereopod 1 is slender, with a larger fixed finger in young males, i.e. of $\mathrm{t}<25 \mathrm{~mm}$ and in females. As for males of intermediate sizes, i.e. of $\mathrm{tl} 25-30 \mathrm{~mm}$, some may have a stout pereopod 1 while others may still retain the slender morphology of this appendage. A similar situation is reported in
Gebiacantha talismani Bouvier, 1915 (see Ngoc-Ho, 2003: 505, Figures 24, 25).

A few small specimens of $G$. priochela bear only one infrarostral spine and show slight relationship with $G$. dampierisp. nov. They can be differentiated by:

1) the shorter antennular peduncle not overreaching the fourth article of that of the antenna.

2) the antennal peduncle with one and three lower spines on the first and third article respectively (vs. first article unarmed and third article with two lower spines in $G$. dampieri).

3) more and larger spines on pereopod 1 that bears also lower tubercles on the lateral surface, absent in $G$. dampieri.

4) uropods about as long as the telson, with exopod truncate on the posterior border (vs. uropods longer than telson, exopod rounded on posterior border in G. dampieri)

\section{Genus Upogebia Leach, 1814}

\section{Upogebia australiensis de Man, 1927} Figure 3

Gebia hirtifrons. - Haswell, 1882: 164-165.

Upogebia octoceras australiensis de Man, 1927: 14 17, pl 2, fig. 7. - 1928: 24, 49.

Upogebia (Calliadne) australiensis. - Hale, 1941 : 273-274, fig. 9. - Poore and Griffin, 1979: 287, fig. 43 .

Upogebia (Upogebia) bowerbankii. - Sakai, 1982: 25.

\section{Material examined}

Western Australia Dampier Archipelago. NMV J 52400 (1 ovig. female, cl $9.0 \mathrm{~mm}, \mathrm{tl} 25.0 \mathrm{~mm}$ [figured]; 1 female, cl $7.0 \mathrm{~mm} ; 2$ males, cl $6.0 \mathrm{~mm}$ and $8.0 \mathrm{~mm}$ ), $4.6 \mathrm{~km}$ SWS of Bluff Pt, Enderby I., $10.5 \mathrm{~m}$, coll. G.C.B. Poore and R.A. King, 28.07.1999; NMV J 52397 (1 female [just moulted, poor condition], cl $9.0 \mathrm{~mm}$; 1 male, $\mathrm{d} 9.5 \mathrm{~mm}), 1.4 \mathrm{~km} \mathrm{E}$ of NE Pt of Goodwyn I., muddy sand, $19 \mathrm{~m}$, coll G.C.B. Poore and R.A. King, 25.07.1999

\section{Other material examined}

Upogebin australiensis

Eastern Australia. ZMA Crust. De 241281 as Upogebia (Calliadne) octoceras Nobili var. australiensis de Man, (1 male; 2 females [1 ovig.]), Port Jackson, New South Wales, in the interior of sponges, coll. de Man 1882; ZMA Crust. De 241278 (1 male, 1 female), coll. and det. de Man, leg. Prof. Chilton 1926; NMV J 16603 (1 male, d $7.0 \mathrm{~mm}$ ), Victoria, Bastion Pt, Mallacoota, reef, coll. G.C.B. Poore and R.S. Wilson, 06.04.1989; NMV J 16594 (1 male, cl $5.0 \mathrm{~mm}$; 1 juv. cl $3.5 \mathrm{~mm}$ ), Shell Harbour, 


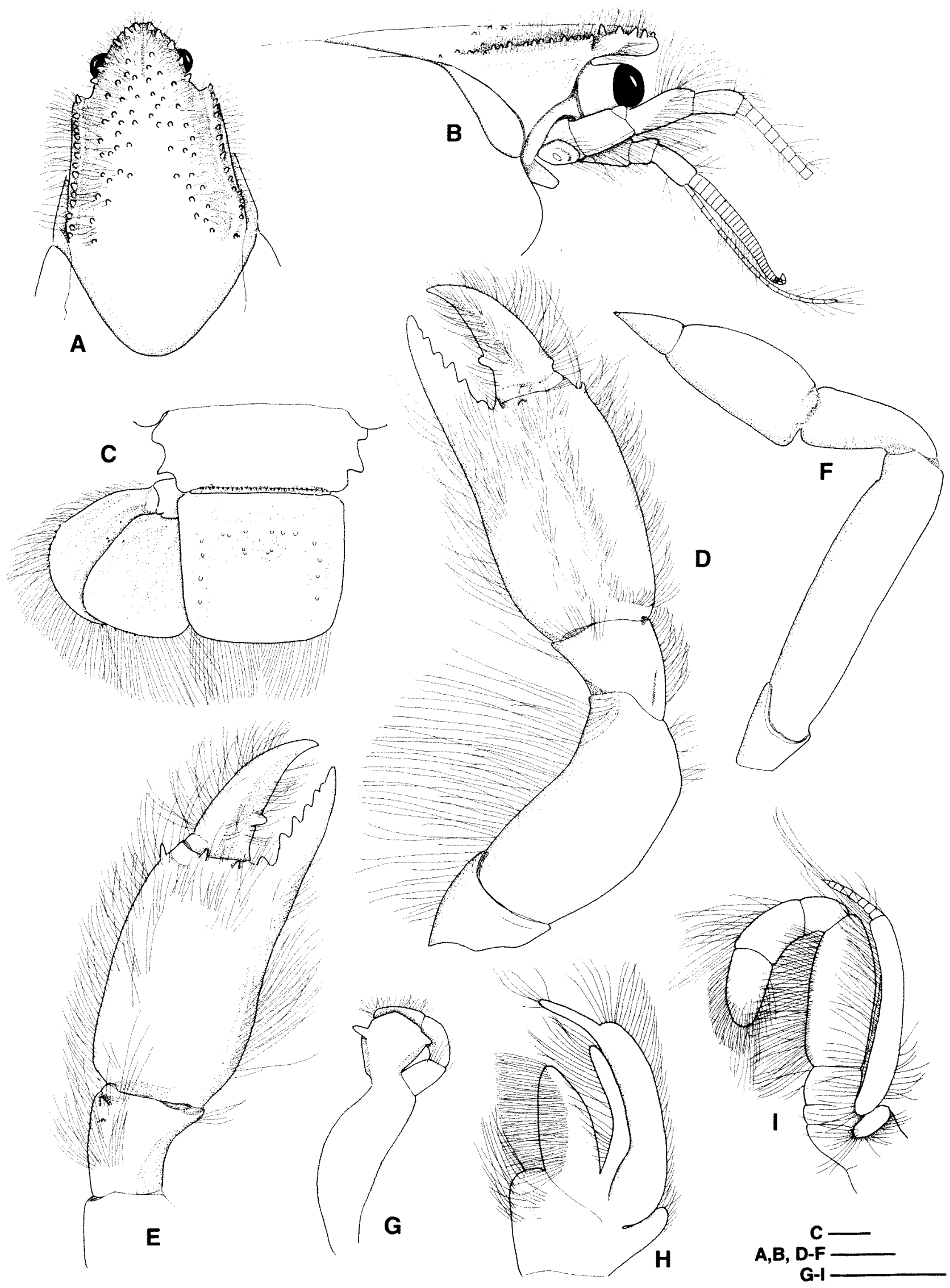

Figure 3 Upogebia australiensis de Man, female (NMV J 52400). A, B, anterior part of carapace; C, telson and uropod; D, E, pereopod 1 and distal part in mesial view; F, pereopod 2; G, mandible; $\mathbf{H}$, maxilliped 1; I, maxilliped 2. Scale: $1 \mathrm{~mm}$. 
New South Wales, coll. I.E. Watson, 1976: MNHN Th 599 (1 male, d $10.5 \mathrm{~mm}$; 2 ovig. females, d 11.5 $\mathrm{mm}, 13.5 \mathrm{~mm})$, New South Wales, coll. Haswell, don. Sydney Museum.

\section{Upogebia bouerbankii (Miers)}

Western Australia. NHML 81.97 (holotype, male, tl $21.4 \mathrm{~mm}$ [according to de Man, 1927]) Fremantle; WAM C 1282-1287 (4 males, cl 12.0-14.0 mm, tl $31.5-37.0 \mathrm{~mm}$; 2 ovig. females, d $11.5 \mathrm{~mm}, 15.0 \mathrm{~mm}$, tl $30.0 \mathrm{~mm}, 39.0 \mathrm{~mm}$ ), Cottesloe.

\section{Upogebia daroinii (Miers)}

Western Australia. WAM C 1288-1290 (3 ovig. females [1 broken)], cl 8.5-14.5 mm, tl 22.0-36.0 $\mathrm{mm}$ ), Cottesloe.

\section{Upogebia tractabilis (Hale)}

Western Australia. WAM C 1291-1231 (15 males, cl $6.0-8.0 \mathrm{~mm}$; 16 females [ 8 ovig.], cl $7.5-10.5 \mathrm{~mm}$; 1 female [figured], cl $10.5 \mathrm{~mm}, \mathrm{tl} 28.5 \mathrm{~mm}$ ), Cottesloe.

\section{Description}

Rostrum (Figures 3A, B) overreaching eyes, lateral borders slightly convex, each with six to eight teeth. Gastric region with weak median anterior groove, lateral ridges bearing 14-18 spines or spiniform tubercles. Anterolateral margin of carapace unarmed, linea thalassinica terminating shortly posterior to cervical groove. Posterior border of $6^{\text {th }}$ abdominal segment often finely denticulated. Telson (Figure 3C) subquadrate, dorsal U-shaped carina with denticles.

Antennular and antennal peduncles (Figure 3B) unarmed; antennular exopod longer than endopod, antennal scale small, bearing no distal spine. Mandible (Figure 3G) carrying lower tooth. First maxilliped (Figure 3H) with epipod; exopod slender distally with a few setae at tip. Second maxilliped (Figure 3I) with epipod folded under base of exopod; no epipod on maxilliped 3. Arthrobranchs with a single tubular structure on either side of the rachis.

Pereopod 1 (Figure 3D, E) chelate, not sexually dimorphic; merus unarmed; carpus with upper mesial subdistal spine, followed by tubercle; propodus with small upper subdistal spine (sometimes very small or missing), tubercle and spine near base of dactylus on lateral surface and two spines on mesial surface, cutting edge of fixed finger bearing six to ten slender teeth; dactylus with slightly curved tip, cutting edge unarmed except for a large round tooth on proximal third. Pereopod 2 (Figure 3F) with propodus approximately twice as long as wide at midlength, and over twice as long as dactylus. Uropod endopod and exopod (Figure $3 \mathrm{C}$ ) about as long as telson.

\section{Distribution}

Australia: Port Jackson (type locality, Haswell, 1882), New South Wales, Queensland (Poore and Griffin, 1979), Dampier Archipelago, Western Australia.

\section{Remarks}

The type material of this species, from Port Jackson, was first assigned to Gebia hirtifrons White by Haswell (1882). De Man (1927) rejected this identification because of the chelate pereopod 1 (subchelate in $U$. hirtifrons). The species was regarded as a variety of $U$. octoceras Nobili, 1904 from the Red Sea, and named $U$. (Calliadne) octoceras var. australiensis de Man. Hale (1941) was the first to elevate it to full specific status and pointed out that the distinctly longer rostrum together with larger eggs justified its separation from $U$. octoceras.

De Man (1927), Hale (1941) and later, Poore and Griffin (1979) considered $U$. australiensis as different from another Australian species, $U$ bowerbankii (Miers, 1884), but Sakai (1982: 24) synonymised the two.

Specimens from the Dampier Archipelago agree well with the materials previously studied by Hale (1941) and Poore and Griffin (1979) except for the rostrum which is here longer, with the lateral borders slightly more convex. It is actually similar to that of the type specimens from Port Jackson examined and depicted by Sakai (1982: Figure 3c). There is also variation in the rostral teeth that are sometimes larger than in the specimen figured (Figure 3A)

The holotype of Upogebia bowerbankii was figured by de Man (1927: figs 4, 4a, 4c) and Sakai (1982, figs $3 b, 4 d-g$ ). The lateral views of the rostrum (Figure $4 \mathrm{~A}$ ) and the pereopod 2 are here added (Figure 4B). Figure 4A shows the unnatural curve of the partly broken rostrum as reported by Sakai (1982: 25) and no spine on the anterolateral border of the carapace, as it was erroneously reported in de Man (1927: 10, fig. 4a).

Also examined in this work is a material comprising 40 specimens from Cottesloe, $W$. Australia assigned to $U$. bowerbankii (WAM C 1282-C 1321) (old No. WAM 10680-10719) which brought Sakai (1982: 25) to synonymise $U$. australiensis with the latter species.

Though reported as coming from a sponge (a large sponge?), the sample includes three species: four males, two ovigerous females of $U$. bowerbankii (WAM C 1282-1287), three ovigerous females of $U$. darwinii (Miers) (one broken) (WAM C 1288-1290), 15 males, 16 females (eight ovigerous) of $U$. tractabilis (Hale) (WAM C 1291-1321).

Specimens of $U$. bowerbankii from Cottestoe are all larger than the holotype. There are variations in the lower border of the pereopod 1 merus that 


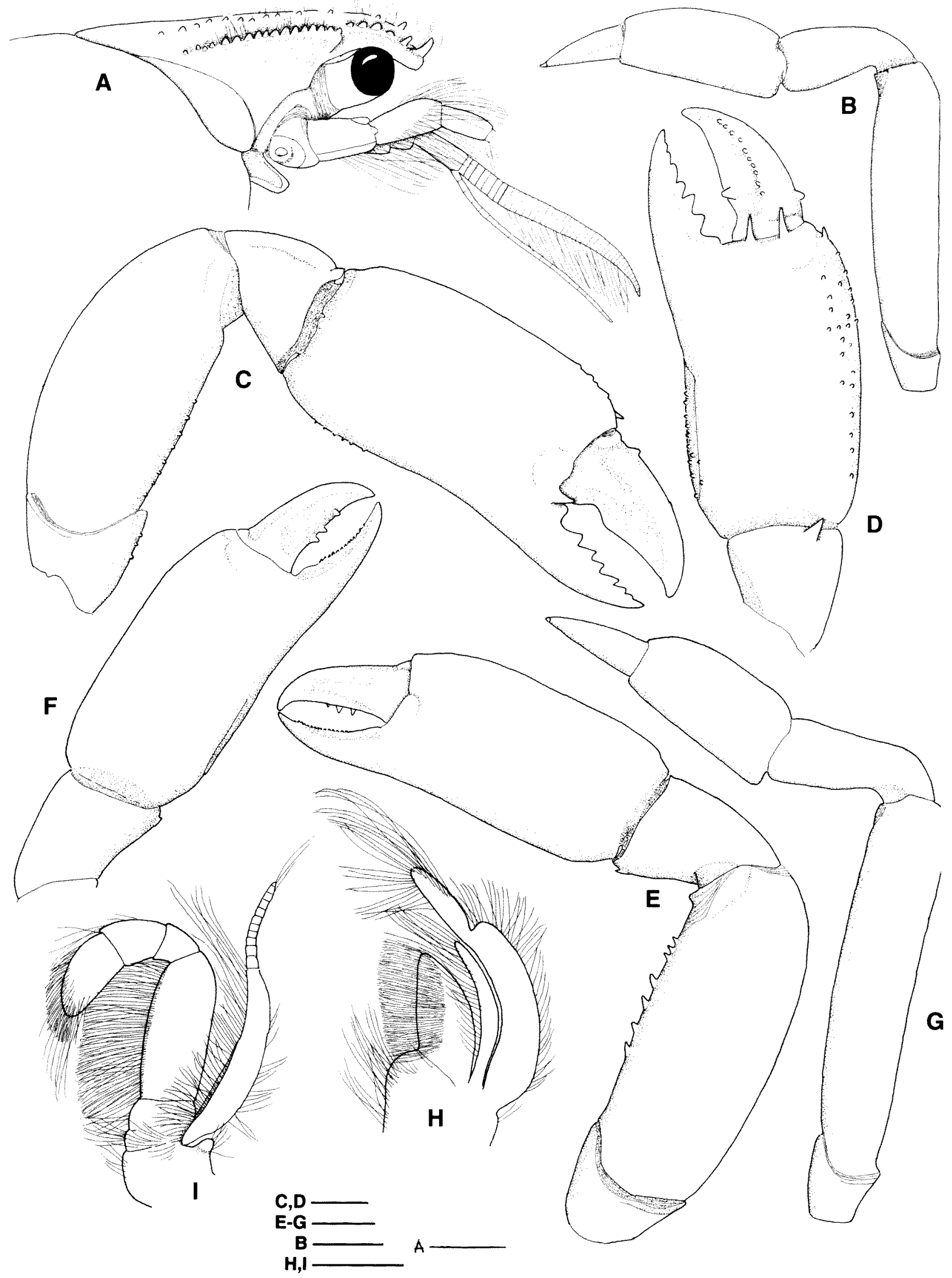

Figure 4 Upogebia bowerbanki (Miers), A, B, holotype, male from Fremantle: (NHML 81.97); C, D, female from Cottesloe: (WAM C 1282). Upogebia tractabilis Hale, from Cottesloe: E-I (WAM C 1291). A, anterior part of carapace in lateral view; B, G pereopod 2; C, D, E, F, pereopod 1 and distal part in mesial view; H, maxilliped 1; I, maxilliped 2. Scale: $1 \mathrm{~mm}$. 
carries, except for one specimen, tubercles rather than spinules (Figure 4C, D), and the telson is only slightly narrower distally than proximally. As in the holotype, the linea thalassinica terminates shortly posterior to the cervical groove but the terminal portion is very faint.

The material studied in this work indicates that $U$. australiensis and $U$. bowerbankii are distinct though closely related by sharing:

1) the rostrum longer than the evestalks.

2) the broad antennular endopod.

3) the cephalic appendages, maxilliped 1 and maxilliped 2 especially, of similar morphology.

4) the pereopod 1 propodus with a distal spine near the base of the dactylus on the lateral surface and two spines on the mesial surface; large teeth on the cutting edge of the fixed finger; the cutting edge of the dactylus with a large round tooth on the proximal third.

5) the posterior border of the $6^{\text {th }}$ abdominal segment often denticulated.

They differ in (characters of $U$. bowerbankii in brackets):

1) the rostrum narrower in $U$. australiensis, leaving the eyes partly visible in dorsal view (vs. rostrum broader, eyes often hidden in dorsal view).

2) the antennular exopod longer than the endopod in $U$. australiensis (vs. antennular exopod about as long as endopod, Figure 4A); variations exist.

3) the pereopod 1 merus unarmed in $U$. australiensis (vs. pereopod 1 merus with lower spinules or tubercles, Figure 4C); pereopod 1 propodus unarmed on the lower and upper border, with small distal spines near the base of the dactylus on lateral and mesial surface in $U$. australiensis (vs, pereopod 1 propodus with denticles on proximal half of lower border, large distal spines near base of dactylus on lateral and mesial surface, numerous tubercles near upper mesial border, Figures 4C, D); the dactylus unarmed on the mesial surface in $U$. australiensis (vs. dactylus with longitudinal row of tubercules on mesial surface, Fig 4D).

4) the pereopod 2 propodus less than twice as long as broad at midlength, with a conical dactylus in $U$. australiensis (vs. pereopod 2 slender with propodus over twice as long as broad at midlength; slender dactylus, Figure 4B).

5) the telson subquadrate with lateral borders nearly parallel in $U$. australiensis (vs. telson with distal border often slightly narrower than proximal).

Specimens of U. darwinii from Cottesloe, as from elsewhere, can be differentiated by a distally truncate rostrum bearing four rostral teeth while those of $U$. tractabilis have a triangular, short rostrum with more teeth (see Hale, 1941: fig. 11a, b and Poore and Griffin, 1979: fig. 55a, b).
The pereopod I of $U$. tractabilis (Figure 4E, F), which is similar to that of $U$. balmaorum treated later in this work, bears no large teeth on the cutting edge of the fixed finger. This species can be distinguished especially by its first and second maxillipeds that were figured and described from the material of the type locality (see $\mathrm{Ngoc}-\mathrm{Ho}, 1994$ : 74, figs $110, f$ ) and found again here: Epipod is absent from the maxilliped 1 (Figure $4 \mathrm{H}$ ) and maxilliped 3. The exopod of the maxilliped 1 is enlarged distally, bearing setae of two lengths with the longer on the external border. Epipod is present on the maxilliped 2 (Figure 41 ), small and not folded but standing upright on the coxa, with a few setae.

Specimens from Cottesloe are larger than the types studied by Hale (largest of $\mathrm{tl} 28.5 \mathrm{~mm}$ vs holotype of tl $21 \mathrm{~mm}$ ). Except for seven specimens, including two ovigerous females in which the linea thalassinica is faint, others have a distinct linea thalassinica terminating at the level of the cervical groove. Eggs are large, of $0.95-1.15 \mathrm{~mm}$ in diameter and of approximately the same size as in specimens from the type locality (MNHN Th 1266).

\section{Upogebia balmaorum Ngoc-Ho, 1990}

Figure 5

Upogebia balmaorum Ngoc-Ho, 1990: 966, figs 1, $2 \mathrm{a}-$ d. $-1994: 77$, fig. $12 \mathrm{a}$.

Upogebia tractabilis. - Sakai, 1993: 91.

\section{Material examined}

Western Australia, Dampier Archipelago. NMV I 52398 (1 male, d $8.5 \mathrm{~mm}$, tl $23.5 \mathrm{~mm}), 6.5 \mathrm{~km}$ WNW of Low I. (off West Intercourse I.), coarse gravel, $10 \mathrm{~m}$, coll. G.C.B. Poore and R.A. King, 24.07.1999.

\section{Other material examined}

\section{Upogebia balmaormm}

Madagascar. MNHN Th 567 (3 females [2 ovig.)], d $5.5-8.5 \mathrm{~mm})$, SE coast, St Luce, $50 \mathrm{~m}$, coll. A. Crosnier, 10.1958; MNHN Th 670 (3 males, d 6.0$8.0 \mathrm{~mm} ; 3$ females [2 ovig., 1 broken], cl 8.5-10.0 $\mathrm{mm})$, Nosy Bé, coll. R. Plante, 11.07.1967.

\section{Distribution}

Seychelles (type locality, Ngoc-Ho, 1990), Dampier Archipelago, western Australia.

\section{Remarks}

The specimen is tentatively assigned to $U$. balmaorum due to its rostrum (Figures 5A, B) which is shorter than the eyestalks, bearing four or five lateral teeth, the linea thalassinica terminating posterior to the cervical groove and the mophology of the mouth appendages, the maxilliped 1 and 2 


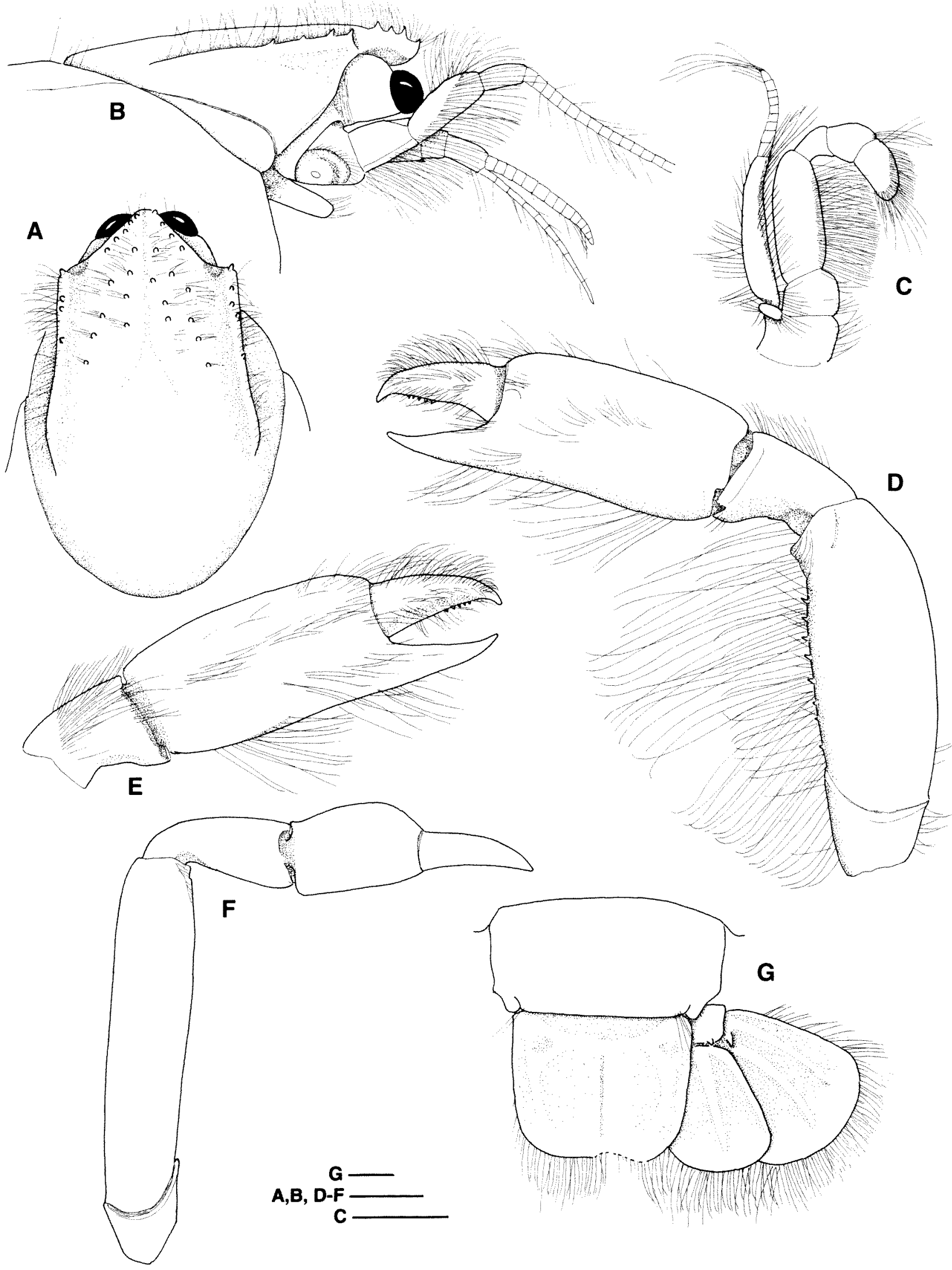

Figure 5 Upogebia balmaorum Ngoc-Ho, male (NMV J 52398). A, B, anterior part of carapace; C, maxilliped 2; D, E, pereopod 1 and distal part in mesial view; F, pereopod 2; G, telson and uropod. Scale: $1 \mathrm{~mm}$ 
especially (Figure 5C). It also agrees with the types in the unarmed pereopod 1 carpus (Figure 5D,E), the pereopod 2 morphology (Figure 5F), the telson (Figure 5G) slightly broader than long, with rounded lateroposterior angles and a proximal spine on the uropodal exopod.

There are variations especially in the pereopod 1 fixed finger and dactylus (see Ngoc-Ho, 1990: fig 1c, $d, f$ ): in the types, the cutting edge of the fixed finger bears small round teeth to the whole extent and the upper border of the dactylus is denticulate while both are unarmed in the present specimen. There are also fewer small triangular teeth on the cutting edge of the dactylus compared to the types and these characteristics bring it near an allied species in the area, Upogebia laemanu $\mathrm{Ngoc}-\mathrm{Ho}$, 1990.

Some specimens of $U$. balmaorum from Madagascar were examined (MNHN Th 567). They have the upper border of the pereopod 1 dactylus unarmed but differ from the present specimen and the types in having a small lower distal spine on the pereopod 1 carpus.

Sakai (1993) synonymised both $U$. balmaorum and $U$. laemanu with $U$. tractabilis and this was discussed in Ngoc-Ho (1994: 77). The Cottesloe material of $U$. tractabilis treated above confirms the distinctness of the latter species as compared with $U$. balmaorum or $U$. laemanu. It can be added that there is a sexual dimorphism of the pereopod 1 (which is more slender in females) in $U$. balmaorum but not in $U$. laemanu and $U$. tractabilis.

\section{Upogebia barbata (Strahl, 1862) \\ Figure 6}

Gebia barbata Strahl, 1862: 388. - Ortmann, 1892: 54.

Upogebia (Upogebia) barbata. - Sakai, 1982: 34, figs 6c, 8b-c. - 1984: 159.

\section{Material examined}

Western Australia, Dampier Archipelago. WAM C 27519, (1 male, ol $8.5 \mathrm{~mm}, \mathrm{tl} 24.0 \mathrm{~mm}$ [figured]; 1 ovig. female, d $7.5 \mathrm{~mm}$, tl $21.5 \mathrm{~mm}$ [figured]); East Lewis I., coll M. Hewitt., 05.09.1999; WAM C 25696 (1 male, cl $6.5 \mathrm{~mm}$ ), Legendre I., limestone with coral cover, interspersed with sand patches and a little coral rubble; many soft corals and Diadema, dive, coll. M. Hewitt et al., 18.10.1998; NMV J 524063 (3 males, d 4.5-8.0 mm; 2 females, cl $6.5 \mathrm{~mm}$ [rostrum broken] and $8.5 \mathrm{~mm}$ ), $3 \mathrm{~km} \mathrm{NW}$ of NW point of Goodwyn l., coral reef rock, $13 \mathrm{~m}$, coll. G.C.B. Poore and R.A. King, 26.07.1999.

\section{Other material examined}

\section{Upogebia barbata}

Philippines. NMB 1131 a (lectotype, female, poor condition, tl $23.0 \mathrm{~mm}$ [according to Sakai, 1982: 34]),
Albay, Luzon; NMB 1131 b (paralectotype, male, cl $6 \mathrm{~mm}$ [selected by Sakai,1982]); Albay, Luzon.

\section{Upogebia ancylodactyla}

NMB 26752 [ex NMB 1131] (1 male, ol $5.5 \mathrm{~m}$ ): Albay, Luzon, Philippines; MNHN Th 6 (16 males, cl $8.5-10.5 \mathrm{~mm} ; 26$ females [24 ovig.], cl 7.0-12.5 $\mathrm{mm}$ ), Aden, Obock and Perim, coll. F.P. Jousseaume, 1897; MNHN Th 7 (2 males, 3 females 11 ovig. [poor condition), coll. Perim, F.P Jousseaume, 1897); MNHN Th 1462 (6 males, cl 5.5$8.5 \mathrm{~mm}$ [figured male, of $\mathrm{cl} 8.5 \mathrm{~mm}, \mathrm{tl} 22.5 \mathrm{~mm}$ ]; 5 females, cl $4.0-8.5 \mathrm{~mm}$ ), Labrador Beach, near Pasir Panjang, Singapore, in coral rock, coll. P. Ng, 01.1992; MNHN Th 1463 (4 females [3 ovig], cl 7.5$8.5 \mathrm{~mm}$ [figured female, cl $8.0 \mathrm{~mm}, \mathrm{tl} 21.5 \mathrm{~mm}$ ]) Sentosa Reef, coll. P. Ng, 1989.

\section{Upogebia carinicauda}

NMB 26751 [ex NMB 1131] (4 ovig. females, cl 6.0-7.5 mm); Albay, Luzon, Philippines.

\section{Description}

Rostrum with four subterminal teeth (Figures 6A, $B$ ), lateral ridge of gastric region divided by a small gap into an anterior half bearing five or six spines and a posterior half with six spinules, this character is variable. Anterolateral border of carapace unarmed; linea thalassinica well defined terminating shortly posterior to cervical groove; Telson (Figure 6C) about 1.2 times broader than long, often slightly broader distally than proximally.

Antennular peduncle (Figure $6 \mathrm{~B}$ ) shorter than that of antenna, reaching approximately half length of its last article; antennal scale membranous or absent.

Pereopod 1 (Figures 6D, E) chelate, merus with spinules on lower border; carpus with upper mesiodistal spine, lower distal spine absent; propodus including fixed finger unarmed; dactylus, with straight or sometimes slightly curved tip, unarmed.

Pereopod 2 (Figure 6F) slender, merus over five times as long as broad, propodus over twice as long as broad at midlength, dactylus less than half length of propodus.

$$
\text { Uropods (Figure 6C) about as long as telson. }
$$

\section{Distribution}

Philippines: Albay, Luzon (type locality, Strahl, 1882); Bay of Djakarta, Indonesia (Sakai, 1984); Dampier Archipelago, Western Australia.

\section{Remarks}

As stated by Sakai (1982:35), the original typeseries of this species, comprising seven specimens (NMB 1131), actually included two specimens of $U$. 


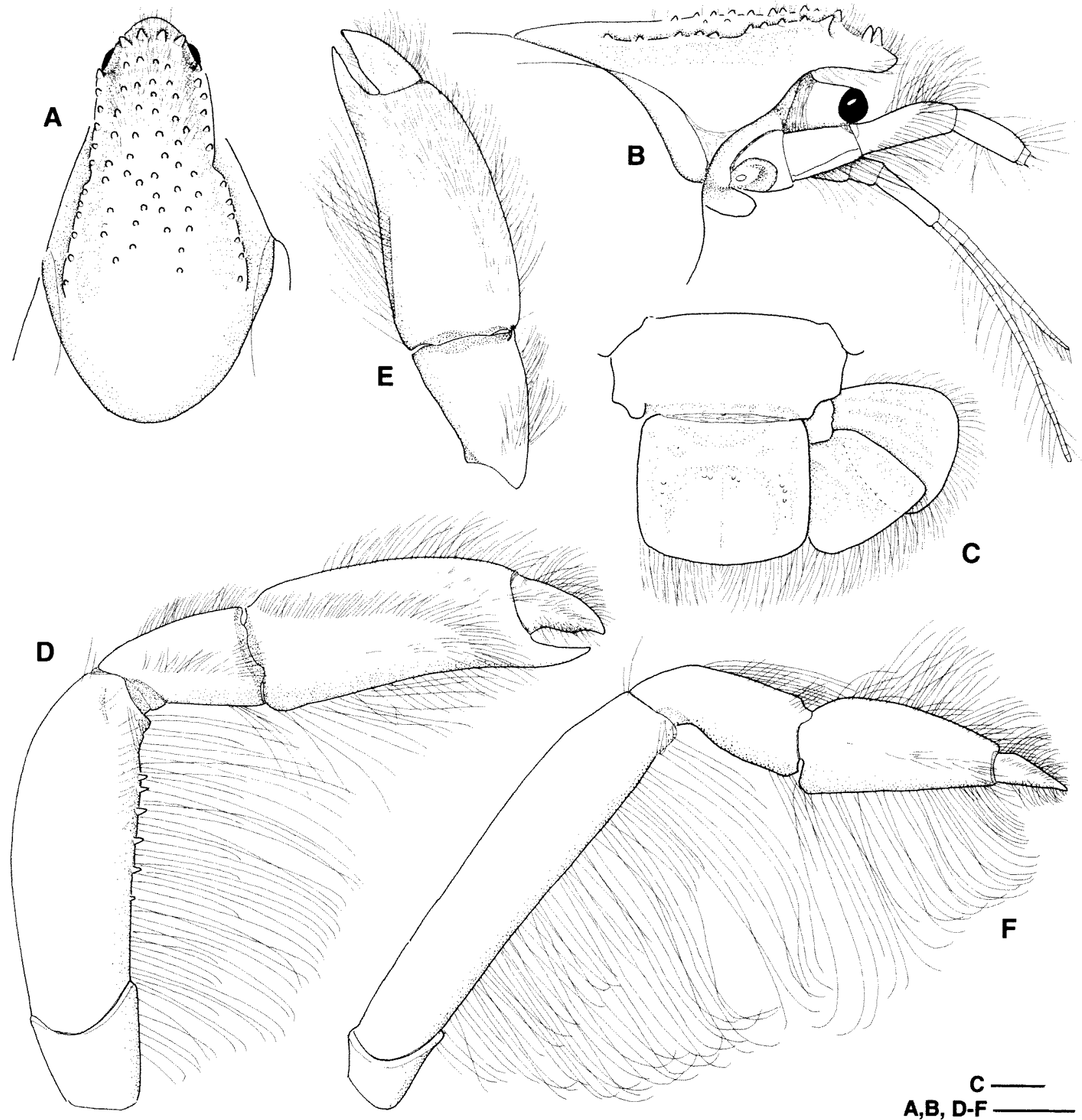

Figure 6 Upogebia barbata (Strahl), female (WAM C 27519). A, B, anterior part of carapace; C, telson and uropod; D, $\mathbf{E}$, pereopod 1 and distal part in mesial view; F, pereopod 2. Scale: $1 \mathrm{~mm}$.

barbata, one of $U$. ancylodactyla de Man and four of $U$. carinicauda (Stimpson).

The female lectotype of $U$. barbata was selected, described and figured by Sakai (1982: 34, figs 6c, $8 \mathrm{~b}, \mathrm{c})$ but is at present in a poor condition. The Dampier material agrees with the figures given, and also with the male paralectotype which is in a better condition than the lectotype. The linea thalassinica, nevertheless, is not visible in the lectotype, due to its condition and hardly so in the paralectotype.
$U$. barbata is closely related to $U$. ancylodactyla de Man and the MNHN material from Aden (MNHN Th 6 and 7) assigned by Sakai (1982: 34) to $U$. barbata actually belongs to the latter species.

Specimens of $U$. ancylodactyla from Singapore are figured for comparison. The two species are similar by having:

1) the rostrum with four upper teeth.

2) the unarmed anterolateral border of carapace.

3) the chelate pereopod 1 with the merus bearing 


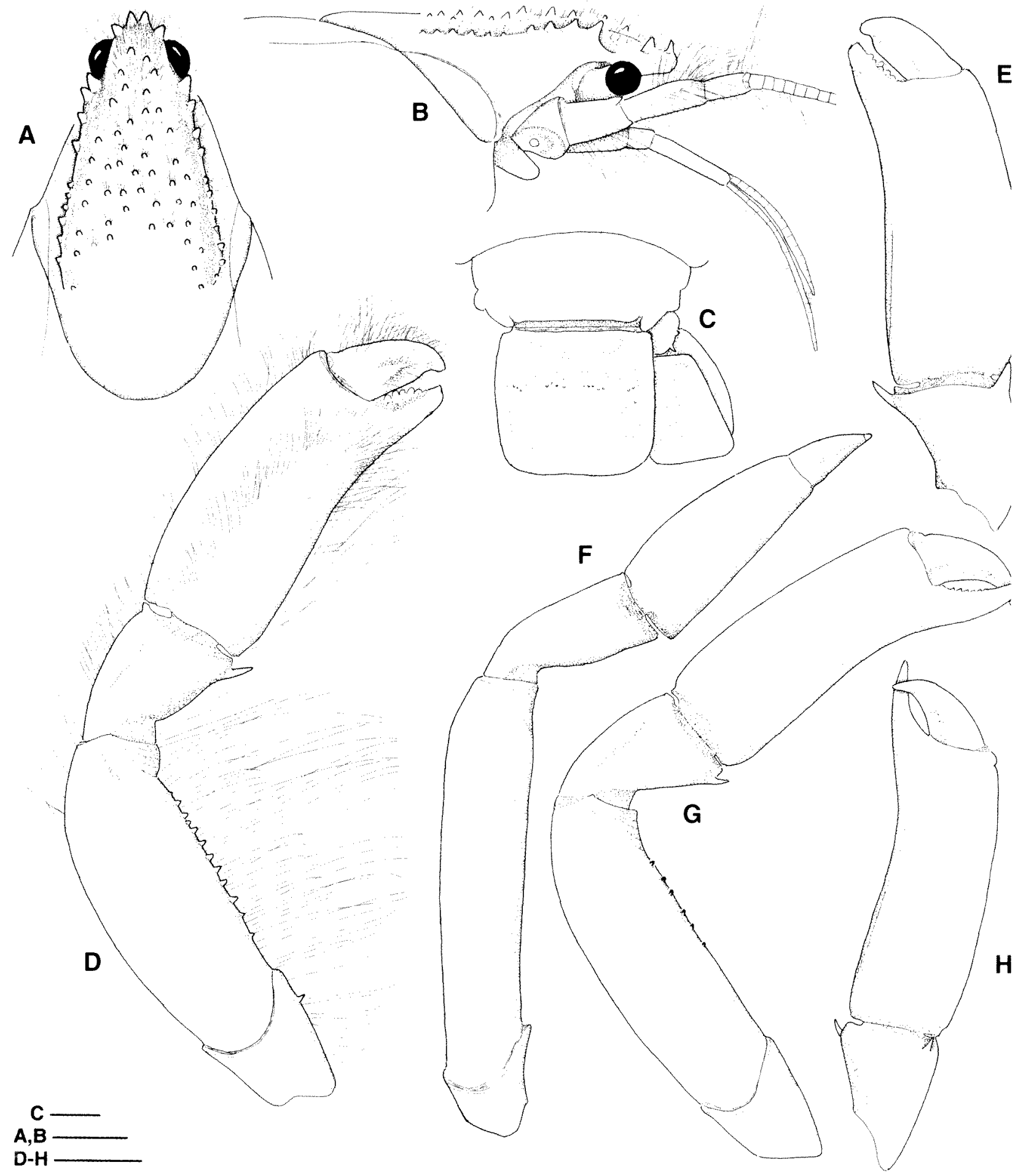

Figure 7 Upogebia ancylodactyla (de Man), A-F, male (MNHN Th 1462), G, H, female (MNHN Th 1463). A, B anterior part of carapace; C, telson and uropod; D, G, pereopod 1; E, H, distal part of pereopod 1 in mesial view; F, pereopod 2. Scale: $1 \mathrm{~mm}$.

lower spinules or tubercles; the propodus unarmed, the dactylus with no proximal round tooth on the cutting edge.

4) a similar morphology of the pereopod 2 .

5) the approximately subquadrate telson.

They differ in:

1) the rostrum usually shorter with subdistal rostral teeth in $U$. barbata; (rostrum usually longer with distal rostral teeth in $U$. ancylodactyla, Figure $7 \mathrm{~A}$ ).

2) the antennular peduncle shorter than that of the antenna and the antennal scale membranous or absent in $U$. barbata (antennular and antennal peduncles approximately of same length, antennal scale present with a pointed tip in $U$. ancylodactyla, Figure 7B). 
3) the pereopod 1 carpus unarmed on the lower border in $U$. barbata (with small or large lower spine in $U$. ancylodactyla, Figure 7D, G).

4) the pereopod 1 dactylus commonly with a straight tip in $U$. barbata (with a strongly curved tip in $U$. ancylodactyla, Figure $7 \mathrm{G}, \mathrm{H}$ ). It can be noted however that, as variations, the P1 dactylus may be slightly curved at tip in $U$. barbata (see Sakai, 1982: Figure 8c) as in $U$. ancylodactyla (Figure 7D, E).

The material of $U$. ancylodactyla from Singapore was collected by Peter $\mathrm{Ng}$ who states (see Lim et al., 1994: 112) that the species has a direct development and eggs hatch as juveniles. In the sample MNHN Th 1463 including three ovigerous females, eggs are approximately of $1.10-1.30 \mathrm{~mm}$ in diameter. Most specimens from Aden (MNHN Th 6) have the telson slightly broader than in those from Singapore (fig. 7C) and eggs are smaller, approximately of 1$1.1 \mathrm{~mm}$ in diameter.

\section{Upogebia carinicauda (Stimpson, 1860)}

\section{Figure 8}

Gebia carinicauda Stimpson, 1860: 23. - de Man, 1888: 256 - Miers, 1884: 280.

Gebia barbata Strahl, 1862: 388. - Ortmann, 1892: 54, fig. 8; 1894: 22.

Gebiopsis Darwinii. - Henderson, 1893: 432.

Upogebia (Upogebia) carinicauda. - de Man, 1928: 60, pl. 3, figs. 6-6c, pl. 4, figs 6d-h. - Sakai, 1982: 35, figs 6d, 8a, pls A5, C5-6. - 1984: 156.

Upogebia (Upogebia) kempi Sankolli, 1972: 671, figs $9,10$.

Upogebia darwini. - Ngoc-Ho, 1977 (part): 444, fig. 4a-e.

Upogebia carinicauda. - Ngoc-Ho, 1979: 153, figs 3c, d.

Upogebia foresti Ngoc-Ho, 1989 (1990): 870, fig. 3.

\section{Material examined}

Western Australia, Dampier Archipelago. WAM C 25557 (1 female [figured], cl $11.5 \mathrm{~mm}$, tl $36.0 \mathrm{~mm}$ ), Searipple Passage, intertidal, many hard corals and sponge, some soft coral, sand flat, scattered lime stone rocks, becoming muddier toward mangals, coll. M. Hewitt et al., 28.10.1998; WAM C 25662 (1 male, $\mathrm{cl} 6.0 \mathrm{~mm}$; 1 juv., cl $3.0 \mathrm{~mm}$ ) and WAM C 25912 (2 ovig. females, cl for both $6.5 \mathrm{~mm}$ ), DA1/98/ 01, Dolphin I., muddy sand, some coral and coral rubble, low relief, gentle slope, dive, coll. M. Hewitt et al., 17.10.1998; WAM C 25663 ( 1 male cl $4.5 \mathrm{~mm}$; 1 ovig. female, cl $7.0 \mathrm{~mm}$ ), Dolphin I., muddy sand, some coral and coral rubble, coll. Hewitt et al., 21.10.1998; WAM C 27522 ( 1 male cl $4.5 \mathrm{~mm}$; 1 female cl $5.5 \mathrm{~mm}$ ), DA3.99/61, West Lewis I., coll. M. Hewitt, 04.09.1999.

\section{Other material examined for comparison}

\section{Upogebia carinicauda}

Currently MNB 26751 (4 ovig. females, cl 6.0-7.5 $\mathrm{mm}$ ), [ex. syntypes of Gebia barbata, Strahl, MNB 1131], Luzon, Albay, Philippines; ZMA De 241 286, Siboga Exp.: ( 3 males, cl 7.5-8.0 mm; 3 females [1 ovig.], cl 6.5-10.0 mm), stn 58, off Seba, Savu: (2 females [1 ovig.], cl $7.0 \mathrm{~mm}, 8.0 \mathrm{~mm}$ ); stn 60 , Samau I., Timor: ( 2 females [ 1 ovig.], cl $5.0 \mathrm{~mm}, 7.0 \mathrm{~mm}$ ), stn 127, Taruna Bay, Great Sangir I.: (1 ovig. female, cl $7.0 \mathrm{~mm}$ ), stn 213, Saleyer anchorage; RMNH D 31749 (1 ovig. female, cl $7.0 \mathrm{~mm}$ ), Samoa, Polynesia; MNHN Th 534 (1 juv, cl $4.0 \mathrm{~mm}$ ) Hongkong, coll. A. Bruce, $243 \mathrm{~m}$; RMNH D 31754 (1 male, cl 6.0 $\mathrm{mm}$ ), Celebes, Indonesia; RMNH D 31751 (16 males, cl $5.0-9.0 \mathrm{~mm} ; 12$ females [ 3 ovig.], cl $6.5-8.5 \mathrm{~mm}$, many with bopyrid parasites) Timor; MNHN Th 1469 (1 female, cl $8.0 \mathrm{~mm}$ ), Bintan, coll. A. Anker, 02.2000; MNHN Th 1471 (2 males, cl $5.0 \mathrm{~mm}$ and $6.0 \mathrm{~mm}$ ), Obi I., $\mathrm{N}$ of Moluccas, $40 \mathrm{~m}$, coll. D.L. Rahayu, 20.01.1994; RMNH D 35736 (1 broken female, cl $11.0 \mathrm{~mm}$ ), Dahlak Arch., Erithrea, Red Sea; MNHN Th 2 (2 males, cl $9.0 \mathrm{~mm}$ and $12.0 \mathrm{~mm}$ ), Pointe du Talus, North Vietnam (= Tonkin), coll. unknown, 15.07.1905; MNHN Th 513 (3 males, cl $8.0-11.5 \mathrm{~mm}$; 1 ovig. female, cl $8.0 \mathrm{~mm}$ ), North Vietnam, coll. Lichtenfelder, date unknown;

MNHN Th 3 (3 females [2 ovig.], cl 14.5-16.5 $\mathrm{mm})$, Cap St Jacques, South Vietnam, coll. Modest, 1908; MNHN Th 4 (1 male, poor condition, cl 6.0 $\mathrm{mm}$ ); Cap St Jacques, South Vietnam, coll. Modest, 1908; MNHN Th 793 (1 male, cl $6.5 \mathrm{~mm}$, poor condition; 3 females, cl $7.5-12.5 \mathrm{~mm}$ ), Cap St Jacques, South Vietnam, coll. Modest, 1909; MNHN Th 515 ( 2 males, cl $5.0 \mathrm{~mm}, 6.0 \mathrm{~mm}$; 3 females, cl $7.0-8.0 \mathrm{~mm}$ ) Cape York, Australia, collector and date unknown; MNHN Th 908 (1 male, cl $5.5 \mathrm{~mm}$ ), Cape York, Australia, collector and date unknown; MNHN Th 1470 (1 juv, 2 males cl $7.0 \mathrm{~mm}, 9.0 \mathrm{~mm}$, 1 female, cl $6.0 \mathrm{~mm}$ ), Cooya, Mossman, Queensland, 0-10 cm, under coral boulders, intertidal, coll. A. Anker, 2003.

\section{Upogebia foresti}

MNHN Th 1048 (paratype: 1 ovig. female, cl 8.5 $\mathrm{mm}$, tl $25.5 \mathrm{~mm}$ ), Siboga Exp., Paleleh, Celebes.

\section{Description}

Rostrum (Figure 8A) overeaching eyestalks, with four distal teeth, anterolateral border of carapace with spine; linea thalassinica on whole carapace with an interruption midway as depicted in Sakai (1982: fig. 6d); epistome with small distal spine. Telson (Figure $8 \mathrm{C}$ ) slightly broader than long, inverted U-shaped carina with prominent transverse ridge.

Antennular peduncle shorter than that of antenna (Figure 8B), latter with small lower distal spine on 


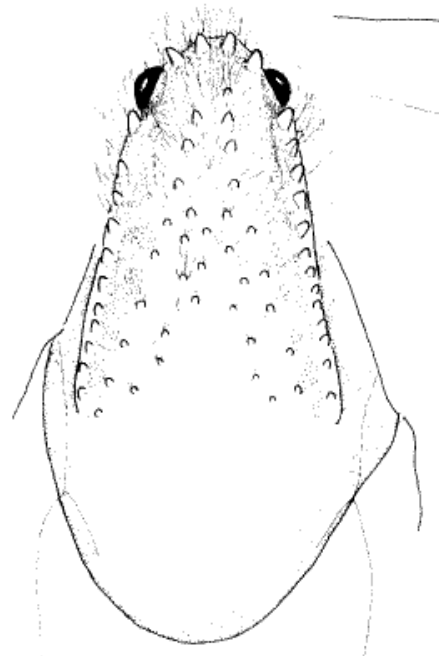

A

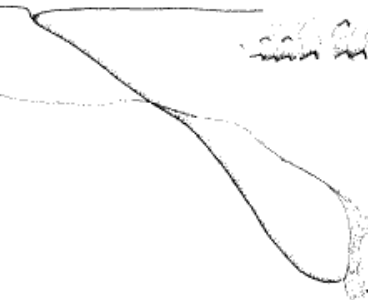

B
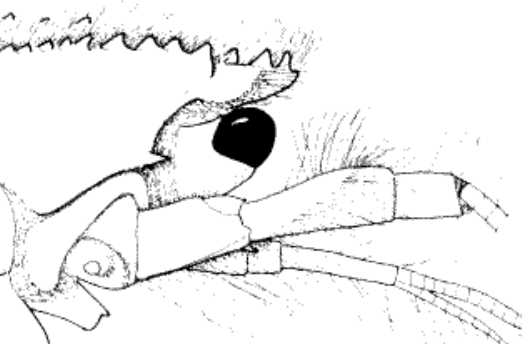

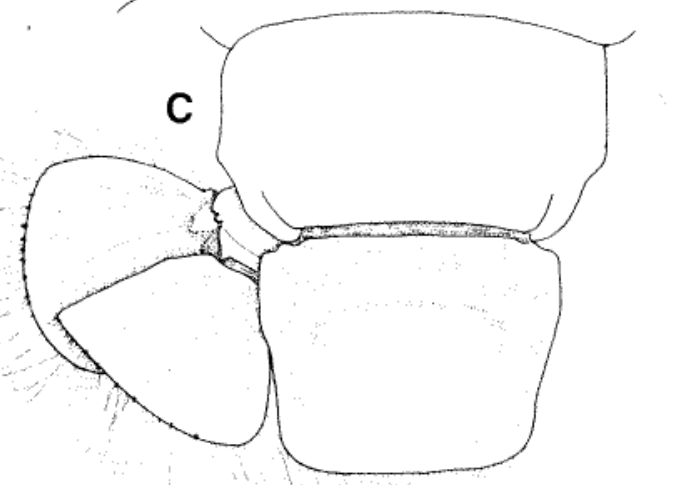

D<smiles>[CH]1C=C[CH+]1</smiles>

D
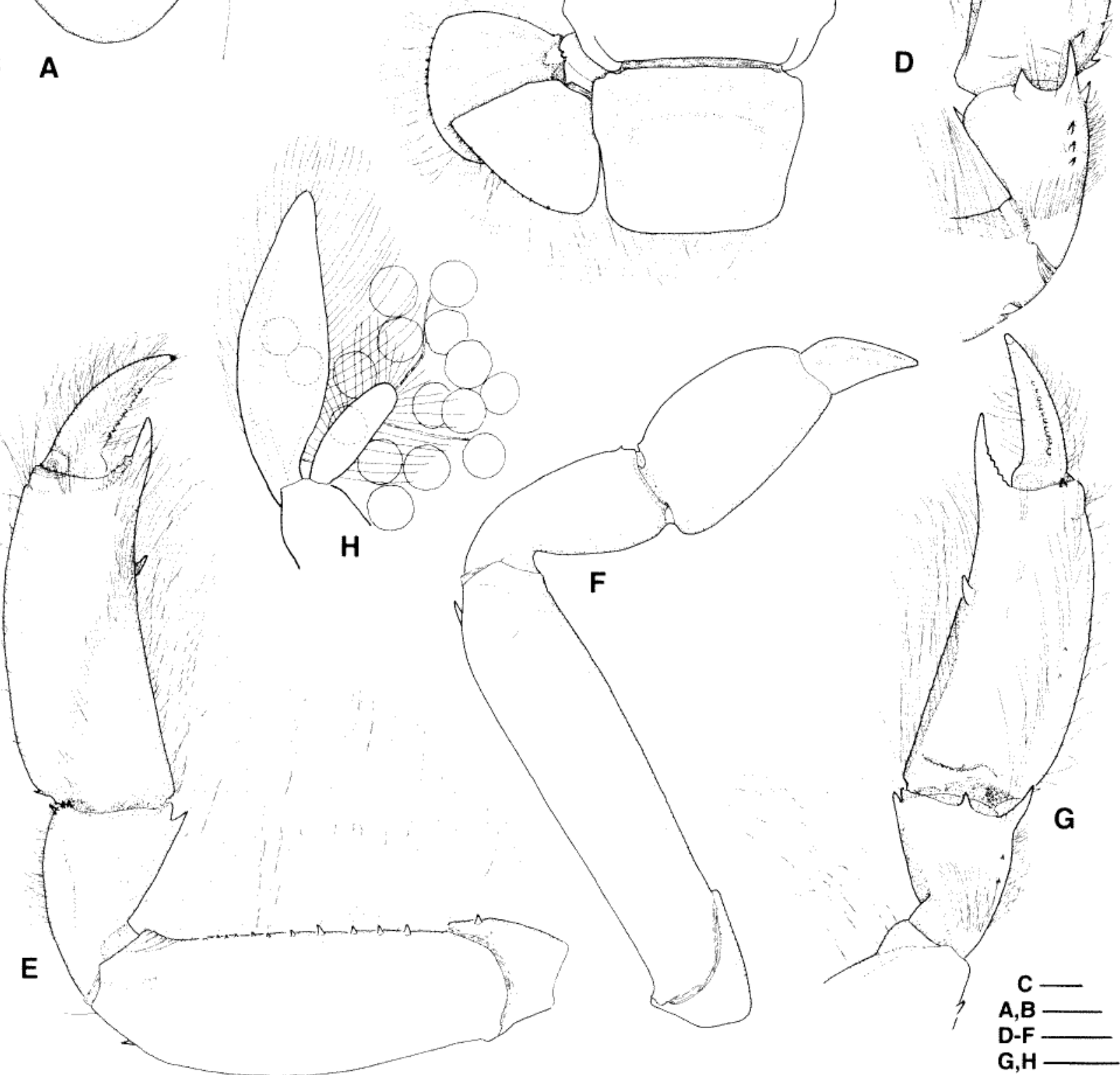

Figure 8 Upogebia carinicauda (Stimpson), A-F, female (WAM C 25557); G, male (RMNH D 31751), H, ovigerous female (WAM C 25663). A, B, anterior part of carapace; C, telson and uropod; E, D, G, pereopod 1 and distal part in mesial view; F, pereopod 2; $\mathbf{H}$, pleopod 3 with eggs. Scale: $1 \mathrm{~mm}$.

article 3. Maxilliped 1 with large epipod, Maxilliped 2 with folded epipod, latter absent from maxilliped 3. Arthrobranchs with double tubular structures on either side of the rachis.
Pereopod 1 (Figures 8D, E, G) subchelate, weak sexual dimorphism; ischium with lower spine; merus with large upper subdistal spine, two to five lower spines or spinules proximally and up to six 
or seven distal tubercles; carpus with large lower and small upper distal spine, latter accompagnied laterally by two or three distal spinules; mesial surface with two large distal spines and two to five spinules along upper border; propodus with longitudinal row of spinules or spiniform tubercles, often starting and terminating by a larger one, along mesial upper border, large spine near distal third of lower border, posterior to fixed finger, latter with small teeth on cutting edge; dactylus with corneous tip, cutting edge denticulated, Iongitudinal row of tubercles on mesial surface. Pereopod 2 (Figure 8F) with upper subdistal spine on merus; propodus stout, about 1.5 times as long as broad; dactylus conical with slight longitudinal upper groove. Pereopod 3, merus with tubercles on lower border. Uropods (Figure 8C.) about as long as telson. Eggs (Figure $8 \mathrm{H}$ ) numerous and small, of $0.55-0.70 \mathrm{~mm}$ in diameter.

\section{Distribution}

Hongkong (type locality, Stimpson, 1860); Indonesia: Ambon, Celebes, Timor (de Man, 1928; Sakai, 1984), Bintan, Obi Island; Bombay, India (Sankolli, 1972); North and South Vietnam; Dahlak Archipelago, Erithrea (Sakai, 1984); Northern Territory, Australia (Sakai, 1993), Cap York, Queensland, Dampier Archipelago, Western Australia.

\section{Remarks}

The female from Dampier, which is described and figured above, is of relatively large size (c) $11 \mathrm{~mm}, \mathrm{tl}$ $36 \mathrm{~mm}$ ). Except for those from North and South Vietnam, other specimens examined are smaller, of $\mathrm{cl}<10 \mathrm{~m}$. Their examination reveals variations in:

1) the rostrum varies slightly in length.

2) the pereopod 1 carpus with a small dorsal spine, not accompagnied by lateral spinules; the propodus spinules or denticles along the mesial upper border are partly or entirely absent, especially in small specimens; the large mesial spine posterior to the fixed finger is sometimes missing.

3) the pereopod 3 propodus often unarmed on the lower border in small specimens.

Upogebia foresti Ngoc-Ho, 1989 from Indonesia was established as a taxon very closely related to $U$. carinicauda but differing by (see Ngoc-Ho, 1989: 872):

1) a shorter rostrum.

2) the pereopod 1 propodus with no mesial distal spine near the base of the dactylus, no spine posterior to the fixed finger.

3) the pereopod 3 merus unarmed.

These however can be considered as variations of $U$. carinicauda. For the mesial spine posterior to the fixed finger on the pereopod 1 propodus, it can be noted that its absence occurs rarely and is not related to the size of the specimens. Nevertheless, in certain samples, e.g. RMNH D 31751 (16 males, 12 females from Indonesia), specimens with this spine on the pereopod 1 propodus (22) or lacking it (6) are found together. They are otherwise all similar and a few may bear the spine on one pereopod 1 only.

Upogebia foresti is here regarded as a junior synonym of $U$. carinicauda. By contrast, an abundant material from Nosy Bé, Madagascar, that was assigned to $U$. carinicauda by Sakai (1982: 35) but pointed out later by Michèle de Saint Laurent as of a new species, is presented below as Upogebia saintlaurentae sp. nov. It is described in comparison with $U$. carinicauda.

\section{Upogebia saintlaurentae sp. nov.} Figure 9

\section{Material examined}

\section{Holotype}

Madagascar. MNHN Th 1472 (1 male, cl $10.5 \mathrm{~mm}$, t] $31.0 \mathrm{~mm}$ [figured]), Nosy Bé, sandstone, coll. A. Crosnier, 1958-1961.

\section{Paratypes}

Madagascar. Same data as holotype: MNHN Th 14731 (male cl $10.0 \mathrm{~mm}$, tl $29.0 \mathrm{~mm}$; 2 females both of $\mathrm{cl} 10.0 \mathrm{~mm}, \mathrm{tl} 30.0 \mathrm{~mm}$ [figured]): MNHN Th 1474 (15 males cl 10.0-10.5 mm, tl 29-30 mm): MNHN Th 1475 (16 females [8 ovig.], cl 10.0-11.0 $\mathrm{mm}, \mathrm{tl} 30.0-32.5 \mathrm{~mm}$ ).

\section{Other material examined}

Madagascar. Type locality. MNHN Th 536 (14 males, cl $6.5-10.5 \mathrm{~mm}$; 66 females [28 ovig.], cl 7.5$11.0 \mathrm{~mm}$ ), sandstone, coll. A. Crosnier, 1958-1961; MNHN Th 524 ( 3 males, cl 9.0-9.5 mm; 6 females, $\mathrm{cl}$ $8.0-10.5 \mathrm{~mm}), 0.70 \mathrm{~m}$, coll. A. Crosnier, 20.05.1958; MNHN Th 525 (4 males, d 9.0-10.0 mm; 11 females [3 ovig.], cl 7.0-10.0 mm), intertidal, 1958; MNHN Th 526 ( 4 males cl $6.0-10.0 \mathrm{~mm} ; 3$ females [1 ovig.], cl 8.5-9.0 mm), sand stone, 16.06.1958; MNHN Th 530 (3 juv., cl $2.5-3.0 \mathrm{~mm}$ [one with abdomen missing]), 1958; MNHN Th 532 (9 males, cl 5.0-10.0 $\mathrm{mm} ; 12$ females [1 ovig.], cl 5.5-10.0 mm; 3 juvs, d 4.0-4.5 mm), sand stone, $0.70 \mathrm{~m}, 02.05 .1958 ; \mathrm{MNHN}$ Th 533 (1 male, cl $11.0 \mathrm{~mm}, 1$ female, cl $10.5 \mathrm{~mm}$ ), intertidal, 02.09. 1974; MNHN Th 523 (2 males, poor condition, cl $6.0 \mathrm{~mm}, 7.0 \mathrm{~mm}$ ), coll. R. Plante, $20 \mathrm{~m}$, fine sand, 22.06.1970; MNHN Th 527 (2 males cl 4.5-5.0 mm); coll. R. Plante, no date; MNHN Th 529 ( 2 males, cl $7.0 \mathrm{~mm}, 9.0 \mathrm{~mm}$; 1 ovig. female, cl 9.0 $\mathrm{mm}$ ), coll. R. Plante, no date; MNHN Th 531 (1 male, cl $5.5 \mathrm{~mm}, 2$ juv., poor condition ), coll. R. Plante, 26.06.1970; MNHN Th 528 (2 females, both of cl $10.5 \mathrm{~mm}$ ), Mission Cherbonnier, coll. 


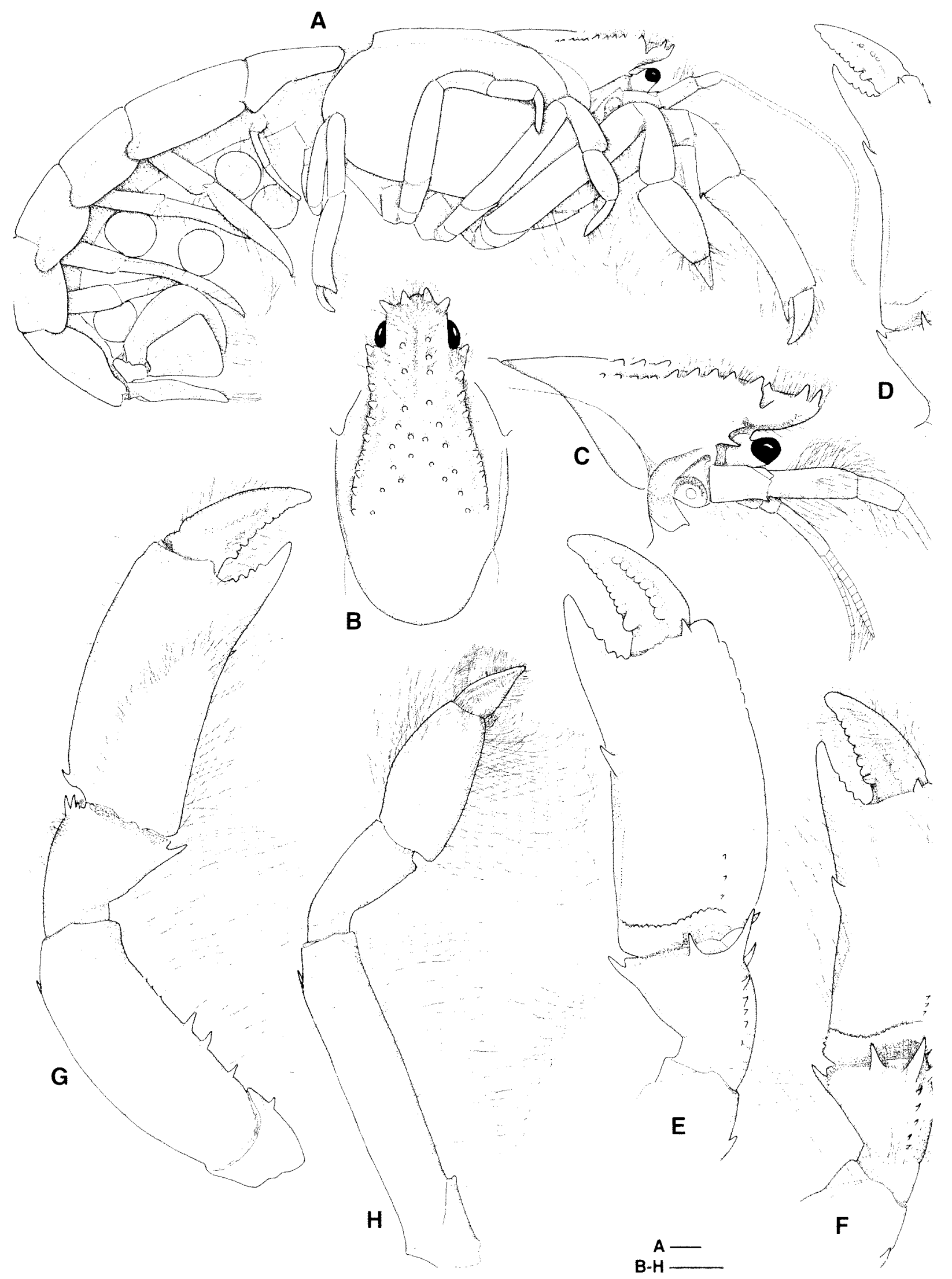

Figure 9 Upogebia saintlaurentae sp. nov. B, C, F-H, holotype, male (MNHN Th 1472); A, ovigerous female, paratype; D, female paratype; E, male paratype (MNHN Th 1473). A, lateral view; B, C, anterior part of carapace; G, D-F, pereopod 1 and distal part in mesial view; H, pereopod 2 . Scale: $1 \mathrm{~mm}$. 
Cherbonnier, 26-31.08.1959; MNHN Th 535 (1 male, cl $9.0 \mathrm{~mm}$; 5 females, cl $8.5-9.5 \mathrm{~mm}$ ), intertidal, Mission Cherbonnier, coll. MacNae, Dec 1958.

\section{Diagnosis}

Rostrum overreaching eyestalks with lateral borders nearly parallel and four distal teeth, anterolateral border of carapace with spine. Telson slightly broader than long, inverted U-shaped carina with prominent transverse ridge.

Pereopod 1 subchelate, sexually dimorphic, merus with large upper subdistal spine and three to five lower spines; carpus with large lower and upper distal spine, mesial surface with two large distal spines and three to five spinules along upper border; propodus with large spine near distal third of lower border; both fixed finger and dactylus with large round teeth on cutting edge, dactylus bearing also large proximal tooth near cutting edge and a longitudinal row of round tubercles on mesial surface. Pereopod 2 with upper subdistal spine on merus and conical dactylus. Pereopod 3 merus with spinules or tubercles on lower border.

\section{Description}

Rostrum (Figure 9A, B) about as long as wide at base, overreaching eyestalks with four distal teeth; anterolateral border of carapace with spine; linea thalassinica (Figure 9A) on whole carapace with an interruption midway; epistome with small distal spine.Gastric region with small round tubercles and shallow groove on anterior part; lateral ridge with 11-12 teeth Telson, as in $U$. carinicauda (Figure 8C) with prominent transverse ridge on inverted $\mathrm{U}$ shaped carina.

Antennular peduncle (Figure 9C) shorter than that of antenna, latter with small lower distal spine on article 3. Mouth appendages and arthrobranchs as in $U$. carinicauda.

Pereopod 1 (Figures 9D, E, F, H) subchelate, sexually dimorphic; ischium with lower spine; merus with large upper subdistal spine, two to five lower spines; carpus with large lower and upper distal spine, latter accompagnied laterally by two or three distal spinules; mesial surface with two large distal spines and two to five spinules along upper border; propodus with small proximal spine on upper border and a few distal denticles; large spine near distal third of lower border posterior to fixed finger, latter with round teeth on cutting edge; dactylus often with no corneous tip, cutting edge with round teeth and a larger one proximally, median longitudinal row of often large tubercles on mesial surface. Pereopod 2 (Figure 9G), pereopod 3 and uropods similar to that of $U$. carinicauda. Eggs are few (Figure 9A) and large, approximately of 1.40-1.55 $\mathrm{mm}$ in diameter.

\section{Type locality}

Nosy Bé, Madagascar.

\section{Etymology}

The species is named for Michèle de Saint Laurent who separated the material.

\section{Remarks}

Upogebia saintlaurentae sp. nov., is closely related to $U$. carinicauda in many features, the spinulation of the rostrum especially, also the subchelate pereopod 1 with a large lower spine on the propodus posterior to the fixed finger, and the shape of the telson.

It differs from $U$. carinicauda by:

1) a longer rostrum with nearly parallel lateral borders.

2) pereopods 1 propodus with unarmed upper border except for the small proximal spine, fixed finger and dactylus both with large round teeth on the cutting edge, that of dactylus bearing also a large proximal round tooth on the mesial surface, and often a median longitudinal row of round tubercles. In most males and also a few females, the dactylus does not terminate in a corneous tip which is likely not absent but worn off.

3) eggs are fewer but over twice as large (Figure $9 \mathrm{~A}$ ) as in $U$. carinicauda (see Figure $8 \mathrm{H}$ ).

In the Upogebiidae, large eggs usually occur in species with a direct development, but that of $U$. saintlaurentae is not known.

$U$. saintlaurentae is also similar to $U$. rupicola Komai, 2005 from Okinawa Island, Japan by the shape of the rostrum, but differs by smaller rostral teeth and the morphology of the pereopod 1. Eggs in the latter species, as in $U$. carinicauda, are much smaller than in $U$. saintlaurentae, of $0.65-0.75 \mathrm{~mm}$ in diameter (Komai, 2005: 266).

\section{Upogebia darwinii (Miers, 1884) \\ Figure 10}

Gebiopsis Darwinii Miers, 1884: 281, pl. 32, fig. 3. Henderson, 1893: 432.

Upogebia darwini. - Hale, 1927: fig. 82. - Ngoc-Ho, 1977: 439, figs 1-13, tabls 1-4.

Upogebia Calliadne darwinii. - Poore and Griffin, 1979 (part): 292.

Upogebia (Upogebia) darwini. - Sakai, 1982: 17, figs 3a, 4a-c, pls A1-3, C3. - 1984: 159.

Upogebia darwinii. - Sakai, 1993: 88.

Not :

Upogebia (Calliadne) Darwinii. - de Man, 1928: 84 (part), pl. 8, figs $12-12 \mathrm{~b}$; pl. 9, fig. $12 \mathrm{c}-12 \mathrm{f}$ (= Gebiopsis intermedia de Man, 1888). 
Upogebia (Calliadne) darwinii. - Poore and Griffin, 1979 (part): 292, fig. 46 (= Gebia carinicauda Stimpson, 1860).

\section{Material examined}

Western Australia, Dampier Archipelago. WAM C 25679 (1 male, cl $8.5 \mathrm{~mm}, \mathrm{tl} 23.0 \mathrm{~mm}$ [figured], 1 female, cl $9.5 \mathrm{~mm}$, tl $26.0 \mathrm{~mm}$ [figured]), Angel I., sponges and soft corals, some hard corals, $8.5 \mathrm{~m}$, dive, coll. Hewitt et al., 29.10.1998; NMV J 52401 (1 male, 1 female, cl $9.0 \mathrm{~mm}$ for both), Enderby I., 4.6 $\mathrm{km}$ SWS of Bluff Pt, coll. G.C.B. Poore and R.A. King, 28.07.1999; NMV J 52402 (1 female, cl 10.0 $\mathrm{mm}$ ), Rosemary I., $2.6 \mathrm{~km}$ ESE of Fish Pt, sandy mud, $10 \mathrm{~m}$, coll. G.C.B. Poore and R.A. King, 26.08.1999; NMV J 52403 (2 females (1 ovig.), cl 7. 5 $\mathrm{mm}$ and $10.0 \mathrm{~mm}), 3.9 \mathrm{~km} \mathrm{E}$ of Nelson Rocks (Mermaid Sound), $21 \mathrm{~m}$, coarse sand/shell, coll. G.C.B. Poore and R.A. King, 18.07.1999; NMV J 524041 (male, cl $11.0 \mathrm{~mm}$; 1 ovig. female, cl 11.5 $\mathrm{mm}), 3.3 \mathrm{~km} \mathrm{~S}$ of Courtenay Head Light on Malus I., $17 \mathrm{~m}$, shelly mud, coll. G.C.B. Poore and R.A. King, 22.07.1999; NMV J 52405 (1 male, cl $8.0 \mathrm{~mm}$ ), $5.4 \mathrm{~km}$ ESE of Courtenay Head Light on Malus I., dredge, $17 \mathrm{~m}$, coll. G.C.B. Poore and R.A. King, 22.07.1999; NMV J 531622 (8 specimens), 4 km NW of Low I. (off West Intercourse I.), sandy mud, dredge, 9m, coll. G.C.B. Poore and R.A. King, 23.07.1999; WAM C 25661 (1 male, cl $4.0 \mathrm{~mm}$ ), Dolphin I., muddy sand, some coral and coral rubble, low relief, gentle slope, dive, coll. M. Hewitt et al., 17.10.1998; WAM C 29571 (ex WAM C 25662) (1 male, cl $5.0 \mathrm{~mm}$; 1 female, cl $4.0 \mathrm{~mm}$ ), Dolphin I., muddy sand, some coral and coral rubble, low relief, gentle slope, dive, coll. M. Hewitt et al, 17.10.1998; WAM C 29572 (ex WAM C 25663) (1 male, cl $4.5 \mathrm{~mm}$; 1 female, cl $5.0 \mathrm{~mm}$ ), Dolphin I., muddy sand, some coral and coral rubble, coll. Hewitt et al., 21.10.1998; WAM C 29439 (1 female, cl $5.0 \mathrm{~mm}$ ), Dolphin I., intertidal sand flat with patches of sponges and scattered rocks, coll. Hewitt et al., 21.10.1998; WAM C 27520 (1 female, cl 6.5 $\mathrm{mm}$ ) and WAM C 27521 (1 male, broken rostrum, $\sim \mathrm{cl} 11.0 \mathrm{~mm}$; 1 female, cl $11.5 \mathrm{~mm}$ ), Nelson Rocks, coll. M. Hewitt, 7.09.1999; WAM C 29442 (1 male, rostrum broken, $\sim \mathrm{cl} 8.0 \mathrm{~mm}), \mathrm{DA} 2 / 99 / 05, \sim 3.5 \mathrm{n}$. $\mathrm{mls}$ NE of C. Legendre $\left(20^{\circ} 19.79^{\prime} \mathrm{S}, 116^{\circ} 53.85^{\prime} \mathrm{E}\right.$ to $\left.20^{\circ} 19.81^{\prime} \mathrm{S}, 116^{\circ} 53.39^{\prime} \mathrm{E}\right)$, rake box dredge, $38.0 \mathrm{~m}$, coll. M. Hewitt, 14.07.1999.

\section{Other material examined}

\section{Upogebia intermedia}

ZMA De 102550 (type: 1 male, ol $12.0 \mathrm{~mm}, \mathrm{tl}$ $36.0 \mathrm{~mm}$ ), Mergui Archipelago, coll. de Man 1857/59; ZMA De 103097 (1 ovig. female, cl 11.0 $\mathrm{mm})$, Siboga Exped. stn 181, Ambon; RMNH D 6686 (4 males, cl $8.0-10.0 \mathrm{~mm}$; 4 ovig. females, cl $8.0-10.0 \mathrm{~mm}$ ), Pulu Kuyper, Bay of Djakarta, 18.07.1941.

\section{Description}

Rostrum (Figure 10A, B) longer than eyestalks with four terminal teeth; anterolateral border of carapace unarmed; linea thalassinica terminating shortly posterior to cervical groove. Posterior border of $6^{\text {th }}$ abdominal segment often finely denticulated (Figure $10 \mathrm{C}$ ), telson rectangular about 1.2 times as wide as long, with posterior border slightly convex, dorsal inverted U-shaped carina present. Maxilliped 1 with small epipod., arthrobranchs with single tubular structure on either side of the rachis.

Pereopod 1 (Figures 10D, E, G) chelate with weak sexual dimorphism; merus unarmed on upper border, lower border bearing 8-14 or 16-18 (rare) spinules, smaller distally or with tubercles; carpus with upper mesial distal spinule, lower distal spine very small or absent; propodus unarmed; fixed finger and dactylus slender, sometimes slightly curved at tip, fixed finger with denticulated cutting edge, that of dactylus bearing a round proximal tooth on mesial surface. Pereopod 2 (Figure 10F) slender with propodus over twice as long as wide at base, dactylus elongate. Uropods (Figure 10C) about as long as telson.

\section{Distribution}

Australia: Port Darwin (type locality, Miers, 1884), Bynoe Harbour, North Shelf Island, Port Essington, North West Shelf (Sakai, 1993), Western Australia including Dampier Archipelago, Queensland (Poore and Griffin, 1979), Phuket, Thailand (Ngoc-Ho, 1977); Ambon, Indonesia (de Man, 1928); Red Sea, Dahlak Archipelago.(Sakai, 1984).

\section{Remarks}

Variations occurs in:

1) the number of rostral teeth: among the material from Dampier, there are five rostral teeth in one specimen, six in another.

2) the lower border of the pereopod 1 merus bears spinules of variable size and number or tubercles or is (rarely) unarmed.

3) the posterior border of the $6^{\text {th }}$ abdominal segment is sometimes smooth.

4) the telson is narrower in young specimens than in large adults.

There is nevertheless no variation regarding the anterolateral border of the carapace that is always unarmed, and so are the upper border of the pereopod 1 and pereopod 2 merus. The material described and depicted by Poore and Griffin (1979: 292, fig. 46) from Western Australia (WAM C 11991) (old No. WAM 32-75) and bearing a spinule on these borders, is likely not of this species but of $U$. carinicauda.

The same can be said of the ovigerous female of $\mathrm{cl}$ $10 \mathrm{~mm}$ and $\mathrm{tl} 32 \mathrm{~mm}$ (BM N 86-52) from Mergui 


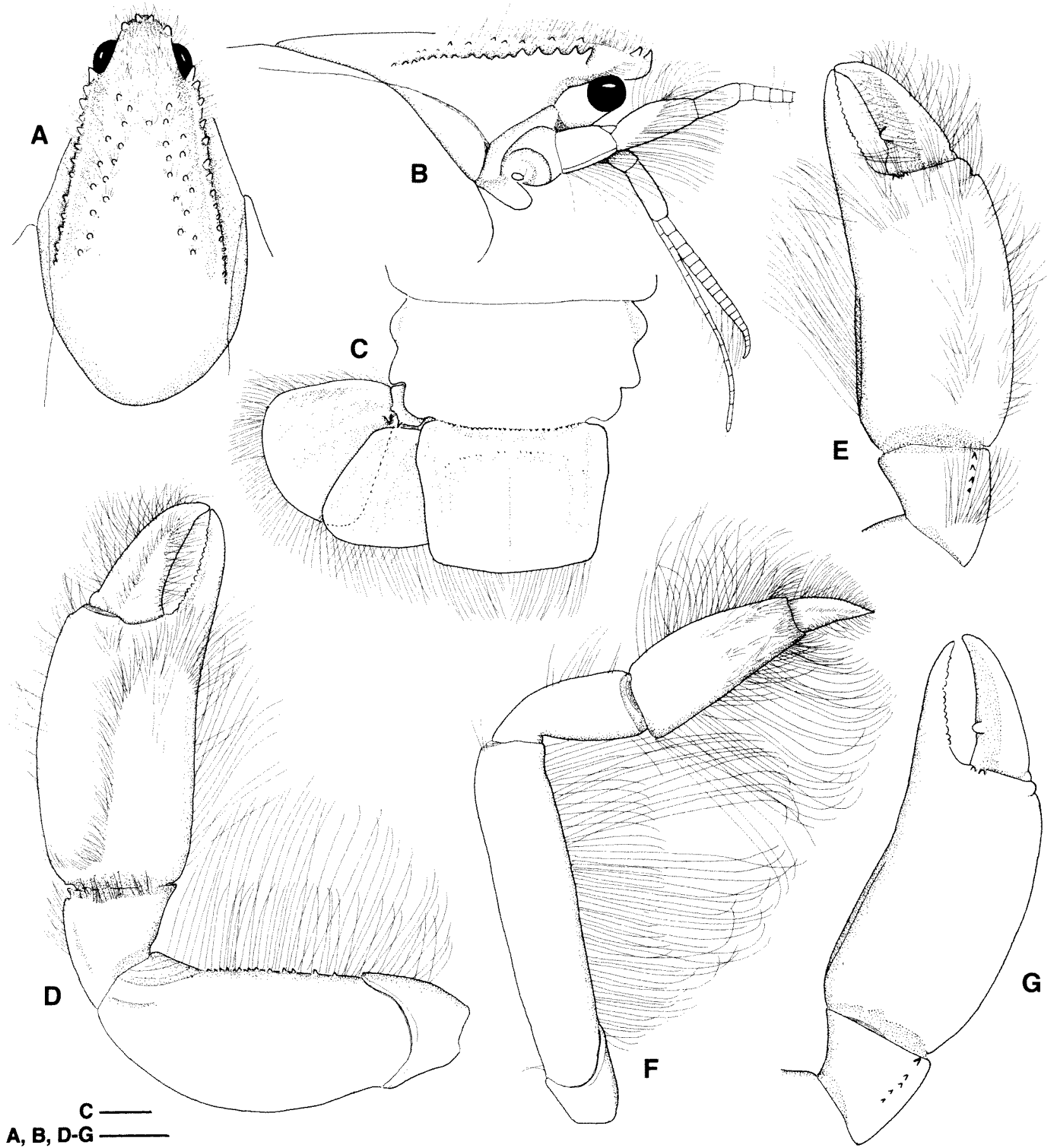

Figure 10 Upogebia darwini (Miers), A-F, male; G, female (WAM C 25679). A, B, anterior part of carapace; C, telson and uropod; D, E, G, pereopod 1 and distal part in mesial view; F, pereopod 2. Scale: $1 \mathrm{~mm}$.

Island presented to the British Museum (Natural History) as a type specimen of Gebiopsis intermedia de Man, 1888. It was examined and figured by Ngoc-Ho (1977: 444, fig. 4), examined by Sakai (1982: 36) and clearly belongs to $U$. carinicauda. It agrees with the original figure (de Man, 1888: pl. 6, fig. 7) especially by the subchelate pereopod 1 and is likely to be the specimen depicted at the time.

However, it disagrees with the original description (de Man, 1888: 256) in which there is no mention of a spine on the upper border of the pereopod 1 and pereopod 2 merus. The pereopod 1 merus is reportedly "armed along the whole length with a row of 25-30 equal minute spinules" and the fingers are "equally long", "the terminal segment (telson) exactly resembles that of Gebiopsis Darwinii", characteristics that are absent from the specimen $B M N^{\circ} 86-52$.

It can be noted that Gebia carinicauda and Gebiopsis intermedia were the only species of the Gebiidae treated in de Man's 1888 paper. There was probably a mistake at some point explaining why a 


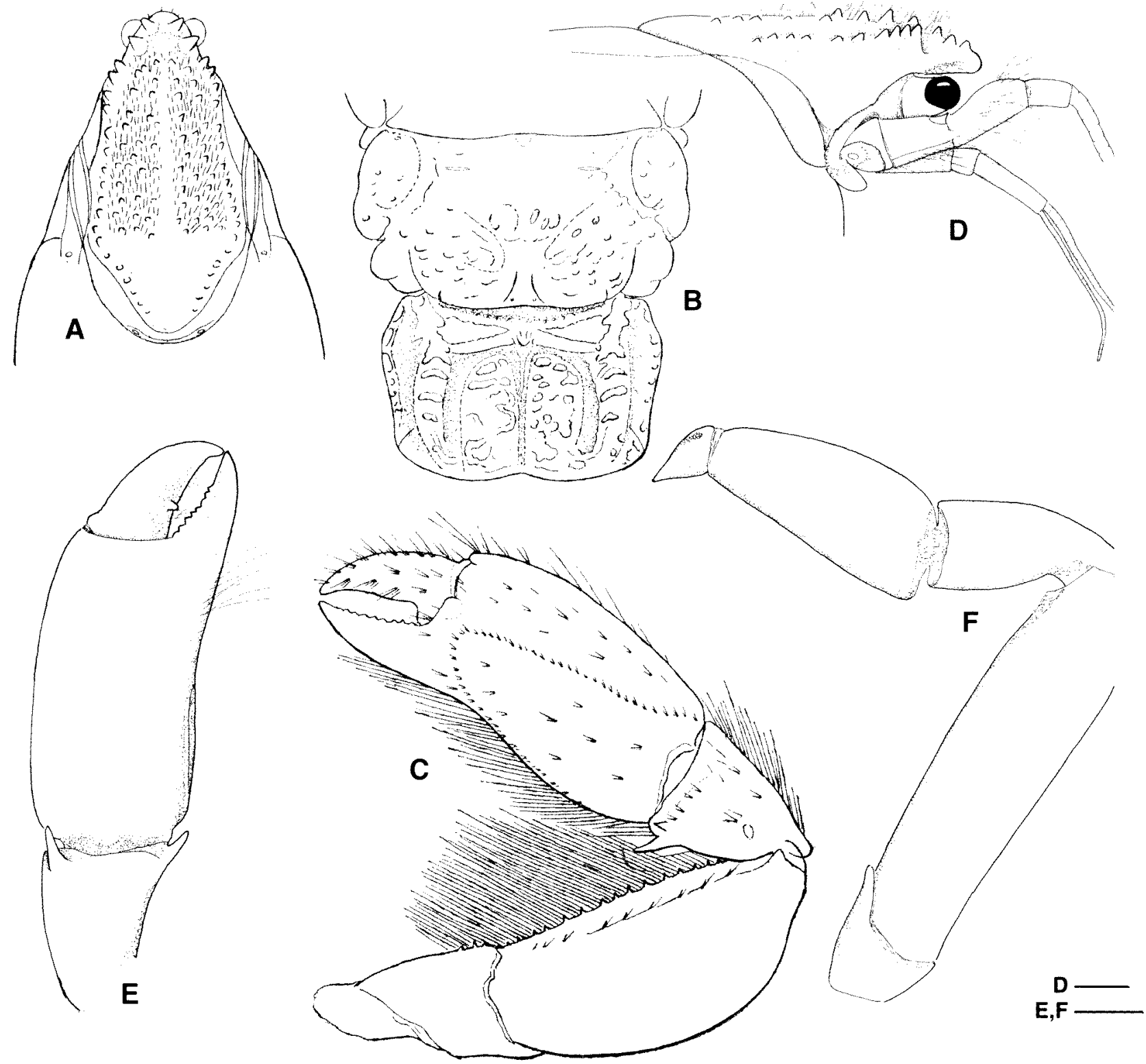

Figure 11 Upogebia intermedia de Man, holotype, male (ZMA 102 550): A-C, from de Man (1928). A, D, anterior part of carapace; B, telson; C, E, pereopod 1 and distal part in mesial view; $\mathbf{F}$, pereopod 2 . Scale: $1 \mathrm{~mm}$.

specimen of the former landed in the collection of the British Museum as a type of the latter. However as it does not fit the original description, it cannot be selected as a lectotype of $U$. intermedia as proposed by Sakai (1982: 37).

The species $U$. intermedia, as de Man (1888) described it, is similar to $U$. darwinii, but the specimen presented to the British Museum, being of $U$. carinicauda, is obviously different. Henderson, nevertheless, (1893; 432), after comparing this specimen with the types of $U$. darwini, considered the two species as identical.

In de Man's work (1888: 256, fig. 7), four adult specimens ( 2 males, 2 females) were reported, one of them is now in the collection of the Museum of Amsterdam (ZMA 102550 ) as a syntype (or the only extant type) of Upogebia intermedia (de Man). This male specimen, of $\mathrm{cl} 12 \mathrm{~mm}$ and $\mathrm{tl} 36 \mathrm{~mm}$, lacks the propodus of both right pereopod 1 and 2 as well as all uropods, but is otherwise in fair condition. It fully agrees with the original description and was described and figured by de Man (1928: 84, figs 12-12f). The figures 12-12b are reproduced here (Figures $11 \mathrm{~A}-\mathrm{C}$ ) and a few others are added (Figures 11D-F).

Sakai (1982: 37) assigned this specimen to $U$. barbata but a comparison with the type of the latter species shows differences: the pereopod 1 merus of U. barbata (see Sakai, 1982, fig. 8c) bears fewer spinules on the lower border; the carpus lacks a lower distal spine and the telson (see Sakai, 1982: 8 b) is much narrower than in $U$. intermedia. 
This work proposes to reinstate Upogebia intermedia (de Man, 1888) as a valid species. It differs from $U$. darwinii by:

1) the rostrum (Figures 11A, B) slightly tapering distally with two distal and two subdistal teeth.

2) the lower border of the pereopod 1 merus (Figure 11C) bearing numerous distinct spinules (15-16 spinules in the type) on its whole lower border; the pereopod 1 carpus (Figure 11E) with a large upper and lower distal spine.

3 ) the unarmed posterior border of the $6^{\text {th }}$ abdominal segment (Figure 11B).

4) the telson (Figure 11B) about one and a half times as wide as long, wider than in $U$. darwini with the posterior border slightly concave medially.

An ovigerous female from Ambon, Siboga St. 181 (ZMA De 103 097) assigned by de Man to $U$. darwinii (1928: 84) and eight specimens from Pulu Kuyper, Djakarta, Indonesia (RMNH D 6686) previously assigned to $U$. barbata, are likely to belong to $U$. intermedia.

The female from Ambon, of cl $11 \mathrm{~mm}$, differs from the type by having fewer spinules (nine-ten) on the lower border of the pereopod 1 merus. The specimens from Djakarta (4 males, cl 5-10 mm, 4 ovigerous females, $\mathrm{cl} 8-10 \mathrm{~mm}$ ) agree well with the type especially in the shape of the rostrum, the pereopod 1 merus bearing numerous spinules (1722) on the lower border, the carpus with a large upper and lower distal spine, the unarmed posterior border of the $6^{\text {th }}$ abdominal segment and the telson which is broader than long. The pereopod 1 dactylus bears a round proximal tooth on the cutting edge; its tip is straight in the two small males of $\mathrm{cl} 5$ and $6 \mathrm{~mm}$, curved in larger specimens. The ovigerous females bear numerous eggs of approximately $0.5-0.65 \mathrm{~mm}$ in diameter.

\section{Upogebia fallax (de Man, 1905)}

Figures 12A, B

Upogebia (Upogebia) fallax de Man, 1905: 601. 1928: 57 , figs $5 \mathrm{a}-\mathrm{g}$.

Upogebia fallax. - Bozic and de Saint Laurent, 1972: 343, tabl. 1. - Ngoc-Ho, 1990: 973, fig. 5c, d. 1995: 81

Upogebia (Upogebia) fallax. - Sakai, 1982: 53 (part, holotype of $U$. fallax only).

Upogebia (Upogebia) pugnax. - Sakai, 1984: 161 (not Upogebia pugnax de Man).

Neogebicula fallax. - Sakai, 1993: 95, figs 3-5.

\section{Material examined}

Western Australia, Dampier Archipelago. NMV J 523960 (1 young male, cl $2.5 \mathrm{~mm}$, tl $7.5 \mathrm{~mm}$ ), 74 $\mathrm{km}$ SE of King Pt, East Lewis I., shelly mud, $12 \mathrm{~m}$, coll. G.C.B. Poore and R.A. King, 27.07.1999.

\section{Distribution}

Indonesia: Samau Island (type locality, de Man, 1905), off Miangas (Sakai, 1984); Australia: Darwin (Sakai, 1993), Dampier Archipelago, Western Australia.

\section{Remarks}

The specimen is much damaged, broken into two pieces, with all pereopods lost. It is here assigned to $U$. fallax due to the shape of the posterior part of its rostrum (Figure $12 \mathrm{~A}$ ), the long $6^{\text {th }}$ abdominal segment, longer than the 2 nd and the uropods (Fig $12 \mathrm{~B})$ that are much longer than the telson.

Sakai (1993) elevated the subgenus Upogebia (Neogebicula) Sakai, 1982 to generic rank, with Upogebia (Neogebicula) alaini Sakai, 1982 as the type species. A number of Upogebia species, including Upogebia fallax de Man 1905, Gebicula monochela Sakai, 1967, Upogebia. contigua Bozic and de Saint Laurent, 1972 and Upogebia gracilis Ngoc-Ho, 1990 were placed in this genus by his action.

Ngoc-Ho (1995: 78) established a new species, Neogebicula wistari from Australia and discussed the definition of the genus referring to its type species, Neogebicula alaini.

Sakai (1993: 95) states that Neogebicula is similar to Upogebia in general features but differs in:

1) the abdominal somite 6 much longer than broad, longer than the somite 2 ;

2) a small telson compared to somite 6;

3) the uropod leaf-like with the exopod much longer than the endopod, the latter much longer than the telson.

If Neogebicula alaini is considered, the following features must be added (see Ngoc-Ho, 1995: 79):

1) the rostrum nearly quadrate in dorsal view, the anterior border rounded with a single distal tooth;

2) the fixed finger on the female pereopod 1 very small, the dactylus stout;

3) female pereopods 1 and 2 of approximately same length, morphology and setation.

As indicated by Poore (1994: 105) in his key to the genera of the Upogebiidae, Neogebicula is related to Wolffogebia Sakai, 1982 and Acutigebia Sakai, 1982. All three are small genera, and by certain characteristics of the mouth appendages and rostral teeth (see Ngoc-Ho, 1995: 81), Neogebicula especially seems highly derived among the Upogebiidae. It can be noted that a single dorsal rostral tooth occurs only in the genus Acutigebia Sakai (with three species) and in Neogebicula.

Ngoc-Ho (1995) agreed with Sakai's assignement (1993) of Gebicula monochela to this genus and added two species, one from Australia, Neogebicula wistari Ngoc-Ho, 1995 and an undescribed Neogebicula sp. from Madagascar. By contrast, it was questionable whether Upogebia fallax de Man, 


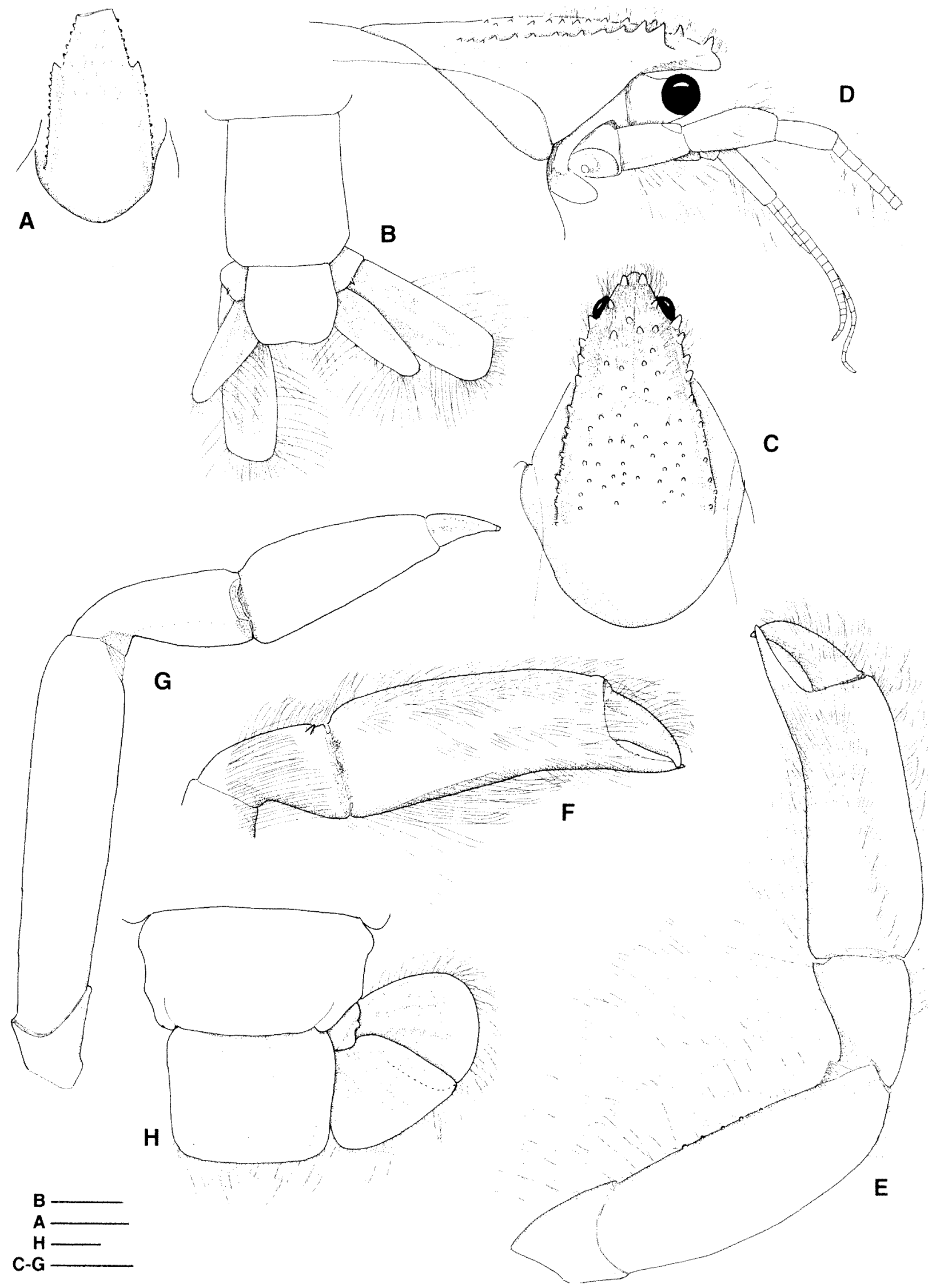

Figure 12 Upogebia fallax de Man, A, B, male (NMV J 52396); Upogebia holthuisi Sakai, D-H, female (NMV) 52407 ). A, C, anterior part of carapace in dorsal view; $\mathbf{D}$, anterior part of carapace in lateral view; $\mathbf{B}, \mathbf{H}$, telson and uropod; E, F, pereopod 1 and distal part in mesial view; G, pereopod 2. Scale: $0.5 \mathrm{~mm}: \mathbf{A}, \mathbf{B} ; 1 \mathrm{~mm}: \mathbf{C}-\mathbf{H}$. 
Upogebia contigua Bozic and de Saint Laurent and Upogebia gracilis Ngoc-Ho should be placed in Neogebicula.

Although having an elongated sixth abdominal segment and long uropods, Upogebia fallax in particular presents features that suggest affinities with taxa other than Neogebicula, as defined by Ngoc-Ho (1995). These are:

1) the rostrum armed with paired dorsal teeth (see de Man, 1928, fig. 5; Sakai 1993, fig. 3A).

2) the female pereopod 1 (described and figured in Sakai, 1993: fig. 5D) presenting no similarity with the pereopod 2.

3 ) in the type (de Man, 1928: fig. 5a) as in other material of $U$. fallax (Figure 12B , also Ngoc-Ho, 1990: fig. 5d; Sakai, 1993: fig. 3c), the posterior border of the telson is concave medially while it is straight in species of Neogebicula.

The species fallax is here retained in the genus Upogebia.

\section{Upogebia holthuisi Sakai, 1982}

Figure $12 \mathrm{C}-\mathrm{H}$

Upogebia amboinensis. - Holthuis, 1953: 51.

Upogebia (Upogebia) holthuisi Sakai, 1982: 33, fig. 6b, 7d-f, 8d. - 1984: 160.

Upogebia holthuisi. - Ngoc-Ho,1991: 299, fig. 8.

\section{Material examined}

Western Australia, Dampier Archipelago. NMV J 52407 (1 ovig. female, cl $7.0 \mathrm{~mm}$, tl $21 \mathrm{~mm}$ ), $4.4 \mathrm{~km}$ East of C. Legendre (Legendre I.), coarse sand, dredge, coll. G.C.B. Poore and R.A. King, 14.07.1999.

\section{Other material examined}

Gebiopsis intermedia amboinensis de Man, 1888 ZMA De 103099 (holotype: female, tl $19.5 \mathrm{~mm}$ ).

\section{Distribution}

Onotoa Island, Gilbert Archipelago (type locality, Holthuis, 1953), New Caledonia (Ngoc-Ho, 1991), Dampier Archipelago, Western Australia.

\section{Remarks}

The female from Dampier was compared with the specimen at present labelled as the holotype of Gebiopsis intermedia amboinensis de Man (ZMA De 103 099) which was described and figured by Tirmizi and Kazmi (1979: 110, fig. 3).

Although the Dampier specimen shares some characters with Upogebia amboinenesis, it is tentatively assigned to Upogebia holthuisi Sakai for the following features:

1) the triangular rostrum with a pair of subdistal and a pair of distal teeth (Figure 12C) (longer rostrum with a pair of distal teeth only in $U$. amboinensis).

2) the pereopod 1 merus with tubercles on the lower border, both the dactylus and fixed finger slender (Figure 12E, F) (pereopod 1 merus unarmed in $U$. amboinensis, dactylus and fixed finger short and stout).

3) the pereopod 2 (Figure 12G) with the same morphology as in specimens of $U$. holthuisi from New Caledonia (see Ngoc-Ho, 1991: fig. 8i).

4) Eggs are of $0.40-0.50 \mathrm{~mm}$ in diameter, about the same size as in the types (Sakai, 1982: 34) and the material of $U$. holthuisi from New Caledonia.

This specimen differs from the typical $U$. holthuisi in:

1) the linea thalassinica not extending to the posterior border of the carapace (Figure 12D).

2) the telson broader than long (Figure 12H).

These discrepancies are considered as variations in $U$. holthuisi; they bring the Dampier specimen near Upogebia amboinensis and show the close relationship of the two species.

\section{ACKNOWLEDGEMENTS}

I wish to thank Gary Poore (National Museum of Victoria, Melbourne) and Diana Jones (Western Australian Museum, Perth) for giving me the opportunity to examine the upogebiid material of the Dampier Archipelago; Gary Poore has also read the manuscript. Thanks are due to Dirk Platvoet for the facilities provided during my visit to the Zoologisch Museum, Amsterdam, to him and Charles Coleman of the Museum of Naturkunde, Berlin for the loan of type materials, also to reviewers who have helped improve the manuscript. "Un grand merci" to Laurent Albenga of the Muséum national d'Histoire naturelle, Paris for scanning some of the figures.

\section{REFERENCES}

Boziè, B. and de Saint Laurent, M. de (1972). Description et position systématique d'Upogebia contigua sp. nov. du Golfe de Guinée (Crustacea Decapoda Callianassidae. Bulletin du Muséum d'Histoire naturelle, Paris 35: 339-346.

Hale, H.M. (1927). The Crustaceans of South Australia. Part I (Eumalacostraca). Adelaide: Government Printer 201 pp. 202 figs.

Hale, H.M. (1941). Decapod Crustacea. B.A.N.Z. Antarctic Research Expedition 1929-1931 Report, Ser. B, $4: 257-285$, figs $1-16$, pl. 3.

Haswell, W.A. (1882). Catalogue of the Australian stalkand sessile-eyed Crustacea. Australian Museum, Sydney: i-xxiv, 1-324 + 2 p. addenda, pls 1-4.

Henderson, J.R. (1893). A contribution to Indian carcinology. Transactions of the Linnean Society, London (Zoology) 5: 325-458, pls 36-40. 
Holthuis, L.B. (1953). Enumeration of the Decapod and Stomatopod Crustacea from Pacific coral islands. Atoll Research Bulletin 24: 1-66.

Komai, T. (2005). A new species of Upogebia (Crustacea: Decapoda: Thalassinidea: Upogebiidae) from Okinawa Island, Ryukyu Islands. Species Diversity 10: $259-268$.

Lim S., Ng P., Tan L. and Chin W.Y. (1994). Rhythm of the Sea. The Lite and Times of Labrador Beach. Nanyang Technological University and The National University of Singapore: $160 \mathrm{pp}$.

Man, J.G., de (1888). Bericht über die im Indischen Archipel von Dr. J. Brock gesammelten Decapoden und Stomatopoden. Archiv für Naturgeschichte 53: 215-600.

Man, J.G., de (1905). Diagnoses of new species of Macrurous Decapod Crustacea from the "Siboga Expedition". Tijdschrift der Nederlandsche Dierkundigr Vereeniging Leiden 9: 587-614.

Man, J.G. de (1927). A contribution to the knowledge of twenty-one species of the genus Upogebia Leach. Capita zoologica 2: 1-58.

Man, J.G. de (1928). The Decapoda of the Siboga Expedition. Part VII. Thalassinidae and Callianassidae collected by the Siboga-Expedition with some remarks on the Laomediidae. Siboga Expeditie Monograph 39 a(6): 1-187.

Miers, E.J. (1884). Crustacea. Report on the Zoological Collections made in the Indo-Pacific Ocean during the Voyage of H.M.S. 'Alert' 1881-2. Part I. The collections from Melanesia. British Museum: London: 178-322, pls 18-32.

Ngoc-Ho, N. (1977). The larval development of Upogebia darwini (Crustacea, Thalassinidea) reared in the laboratory, with a redescription of the adult. Journal of Zoology 181: 439-464.

Ngoc-Ho, N. (1979). A taxonomic study of six species of Upogebia Leach (Crustacea, Decapoda, Thalassinidea) in the collections of the British Museum (Natural History), London. Bulletin of the British Museum Natural History 35: 147-16.

Ngoc-Ho, N. (1981). A taxonomic study of the larvae of four thalassinid species (Decapoda, Thalassinidea) from the Gulf of Mexico. Bulletin of the British Museum, Natural History 40: 237-273.

Ngoc-Ho, N. (1989). Description de trois especes nouvelles de la famille des Upogebiidae (Crustacea, Thalassinidea). Bulletin du Muséum national d'Histoire naturelle' 11: 865-878

Ngoc-Ho, N. (1990). Nine Indo-Pacific species of Upogebia Leach (Crustacea: Thalassinidea: Upobgebiidae), Journal of Natural History 24: 965985.

Ngoc-Ho, N. (1991). Sur quelques Callianassidae et Upogebiidae de Nouvelle Calédonie (Crustacéa, Thalassinidea). In Richer de Forges, B (éd.), Le benthos des fonds meubles des lagons de Nouvelle Caledonie 1: 281-311, figs 1-11. ORSTOM Editions, Paris.
Ngoc-Ho, N. (1994). Some Callianassidae and Upogebiidae from Australia with description of four new species (Crustacea: Decapoda: Thalassinidea). Memoirs of the Museum of Victoria 54: 51-78.

Ngoc-Ho, N. (1995). Neogebicula wistari, new species from Australia, with a redefinition of Neogebicula Sakai, 1982 (Crustacea: Thalassinidea: Upogebiidae). Crustacean Research 24: 78-84.

Ngoc-Ho, N. (2003). European and Mediterranean Thalassinidea (Crustacea, Decapoda). Zoosystema 25: 439-555.

Ortmann, A. (1891). Die-Decapoden-Krebse des Strassburger museums. III. Die abtheilungen der Reptantia Boas: Homaridea, Loricata und Thalassinidea. Zoologische Jahrbücher 6: 1-58.

Ortmann, A. (1893). Decapoden und Schizopoden der Plankton-Expedition. In, Ergebnisse der PlanktonExpedition der Humbold-Stiftung 2: 1-120. G. b. Kiel und Leipzig. Lipsius und Tischer.

Ortmann, A. (1894). Crustaceen. In Semon, R., Zoologische Forschungsreisen in Australien und dem Malayischen Archipel. Denkschriften der Medicinisch-naturwissenschaftlichen Gessellschaft zu Jena $8:$ : $1-80$.

Poore, G.C.B. (1994). A phylogeny of the families of Thalassinidea (Crustacea: Decapoda) with keys to families and genera. Memoirs of the Museum of Victoria 54: 79-120.

Poore, G.C.B. and Griffin, D.I.G. (1979). The Thalassinidea (Crustacea: Decapoda) of Australia. Records of the Australian Museum 12: 217-321.

Saint Laurent, M. de and Ngoc-Ho, N. (1979). Description de deux espèces nouvelles du genre Upogebia Leach, 1814 (Decapoda, Upogebiidae). Crustaceana 37: 57 70 .

Sakai, K. (1982). Revision of Upogebiidae (Decapoda, Thalassinidea) in the Indo-West Pacific Region. Researches on Crustacea, Special number 1: 1-106.

Sakai, K. (1984). Some Upogebiidae (Crustacea, Decapoda) in the collection of the Rijksmuseum van Natuurlijke Historie, Leiden. Zoölogische Mededelingen 58: 149-162.

Sakai, K. (1993). On a collection of Upogebiidae (Crustacea, Thalassinidea) from the Northern Territory Museum, Australia, with the description of two new species. The Beagle 10: 87-114.

Sankolli, K.N. (1972). The Thalassinoidea (Crustacea, Anomura) of Maharashtra. Journal of Bombay Natural History Society 68: 671-682.

Stimpson, W. (1860). Crustacea Macrura. Pars VIII of Prodromus descriptionis animalium evertebratorum, quae in Expeditione ad Oceanum Pacificum Septentrionalem, a Republica Federata missa, Cadwaladaro Ringgold et Johanne Rodgers Ducibus, observavit et descripsit. Proceedings of the Academy of Natural Sciences of Philadelphia 12: 22-47.

Strahl, C. (1862). On some new Thalassinae sent from the Philippines by M. Jagor, and on the systematic position of that family (translation). Annals and Magazine of Natural History 9: 383-396. 


\section{NOTE ADDED IN PROOF}

Since the present work was submitted, a monograph by Sakai (2006) has been published. It deals with the world fauna including a number of the taxa presented herein that are briefly discussed below.

Sakai divides the family into two subfamilies: Upogebiinae and Neogebiculinae, erects three new genera and synonymises others. Sakai attributes Neogebiculinae to Sakai, 1982, whereas it is in fact newly erected.

Eleven genera are recognised by Sakai: Neogebicula Sakai, 1982 (3 species), Paragebicula Sakai, 2006 (5 species), Acutigebia Sakai, 1982 (5 species), Aethogebia Williams, 1993 (monotypic), Arabigebicula Sakai, 2006 (monotypic), Gebicula Alcock, 1901 (2 species), Mantisgebia Sakai, 2006 (2 species), Pomatogebia Williams and Ngoc-Ho, 1990 (3 species), Tuerkayogebia Sakai, 1982 (monotypic), Upogebia Leach, 1814 (131 species), Wolffogebia Sakai, 1982 (5 species). The genus Upogebia is very large compared to all the others.

Several of the synonymies proposed by Sakai impact on this work.

1) The genera Gebiacantha Ngoc-Ho, 1989 and Austinogebia Ngoc-Ho, 2001 were made junior synonyms of Upogebia during discussion of the subfamily Upogebiinae (p. 12) and again under the genus Upogebia (p. 39). Yet many arguments presented are either confusing or erroneous.

As stated for Gebiacantha (see Ngoc-Ho, 1989: 119), given that upogebiid species are very similar to one another, this genus and also Austinogebia were defined not by one but a set of characters including those of mouth appendages. Only specimens possessing all characters of the set were assigned to the genus. Similarities and differences between the two genera can be found in Ngoc-Ho (2001: 50).

Sakai however considered the characters one by one:

a) He quoted (p. 13) upogebiid species with infrarostral spines and their variations, then concluded: "the presence of infrarostral spines is not available as a generic character so that neither Gebiacantha nor Austinogebia are to be separated from Upogebia".

Infrarostral spines alone are not a generic character. Gebiacantha and Austinogebia share this character but can be separated by several others, including the morphology of maxilliped 1, without an epipod in the former genus or with a large epipod in the latter.

b) The lateral ridges of the gastric region in Austinogebia (Ngoc-Ho, 2001) were regarded as projecting forwards, with the upper half thickened and densely setose and 1-3 lower distal spines (as figured in Sakai and Tuerkay, 1995, fig. 1a; or Ngoc-
Ho and Chan, 1992, fig. 1A). This character is unique to the genus but Sakai took into account a part of it only and stated (p. 14): "the lateral ridges of the gastric region are usually protruding forward in most of the species of Upogebia .... and in species of Gebiacantha, ... so it is difficult to separate those two genera from Upogebia based on this character. ".

c) He similarly examined separately the uropodal endopod bearing a proximal knob in Austinogebia or the concave posterior margin of the telson in Gebiacantha. These characters actually exist in other species of Upogebia, therefore, synonymy of Gebiacantha and Austinogebia with Upogebia was the simplest way for him.

A number of incorrect statements occur, i.e.:

a) p. 17: "Ngoc-Ho (2001b: 47) once transferred Gebicula to Gebiacantha",

but Ngoc-Ho never did and the genus Gebicula was not mentioned on the page cited.

b) same page "later establishes the genus Austinogebia Ngoc-Ho, 2001 based on some species from Gebiacantha Ngoc-Ho, 1989'.

No Austinogebia species were taken from Gebiacantha.

c) p. 40: "in the males of two species of Austinogebia, A. edulis and A. wuhsienweni, the ventral margin of the $P 1$ palm bears a disticnct spine posterior to the fixed finger".

No such spine actually exits.

2) Sakai (p. 90) synonymised Upogebia australiensis with Upogebia bowerbankii while both species are regarded as valid and discussed in the present work.

3) Upogebia carinicauda (Stimpson, 1860). In the present work, Upogebia foresti Ngoc-Ho, 1989 is considered synonymous with $U$. carinicauda, as was Upogebia kempi Sankolli, 1972 previously (Ngoc-Ho, 1979).

Sakai (p. 99) gave no diagnosis for the species. He revived $U$. kempi and stated (p. 100) "the species $U$. foresti Ngoc-Ho and U. carinicauda (Stimpson) are different, because in $U$. foresti the $P 2$ merus bears a subdistal spine on the dorsal margin as in U. kempi, whereas in $U$. carinicauda and $U$. rupicola, the $P 2$ merus is unarmed".

$U$. foresti was therefore synonymised with $U$. kempi and $U$. rupicola with $U$. carinicauda.

P2 merus actually bears a dorsal subdistal spine in all four species mentioned above, in $U$. carinicauda especially (see Figure 8). It is small in $U$. rupicola but usually present (Komai, 2005: 265, fig. $4 \mathrm{~F}$ ), except in the holotype (Figure 3B).

Another statement by Sakai (p. 100): "The present author earlier (Sakai, 1982: 35) identified the Upogebia darwinii reported by Ngoc-Ho (1977a, 
fig. 4a-e) as U. carinicauda (Stimpson, 1860); however the width of the uropodal endopod is indeed larger than that in U. carinicauda (cf. NgocHo, 1977a) so it does belong to U. darwinii".

The specimen mentioned above is treated in the present work (p. 146) and also in Ngoc-Ho (1977: 444, fig. 4a-e). It was a specimen presented by de Man to the British Museum as the type of Gebiopsis intermedia which Henderson (1893) synonymised with Gebiopsis darwinii. Ngoc-Ho (1977) described and figured its characteristics showing that it could not be assigned to $U$. darwinii but was near $U$. carinicauda; she nevertheless, did not put the name $U$. carinicauda on the fig. 4 .

It can be noted that $U$. carinicauda is very different from $U$. darwinii although both bear four distal rostral teeth. $U$. carinicauda differs especially by having a spine on the anterolateral border of the carapace, a P1 subchelate, P1 and P2 merus with a dorsal subdistal spine, the telson with a prominent transverse carina, all of these absent from $U$. darwinii.

It is surprising that Sakai switched his identification from one species to the other simply on the basis of the width of the uropodal endopod.

Further in the book however (p. 119), under $U$ intermedia (De Man, 1887), with another wrong statement ["this species was handled as a synonym of U. darwinii by Ngoc-Ho (1977: 444)]", Sakai conceded "but later identified as a complex of two species, Upogebia barbata (Strahl, 1862a) and Upogebia carinicauda (Stimpson, 1860) by Sakai (1982: 34$)^{\prime \prime}$.

4) Upogebia darwinii (Miers, 1884) (p. 101).

A specimen belonging to a species might possess, as variations, one or two characters that bring it near another congener. In my view, this does not mean the two species are indistinguishable.

For Sakai apparently, in this case, the two taxa should be synonymised, as in the case of $U$. darwinii. He once (1982) synonymised $U$. hexaceras (Ortmann, 1894) and $U$. octoceras Nobili, 1904 with
U. darwinii but Ngoc-Ho (1990) considered all three as valid species.

Sakai (2006) considered again his earlier synonymisation and examined numerous specimens. Certain specimens $(p .108,109)$ are to be assigned to $U$. hexaceras but the form of the telson is different, or having 10 frontal teeth as in $U$. octoceras, or the form of the telson should rather be attributed to $U$. darwinii etc. He also erroneously stated (p. 113): "These type specimens (of $U$. darwinii) were examined by Ngoc-Ho (1977) and by Sakai (1982)....., the rostrum bears four frontal teeth and the P1 merus is unarmed on the ventral margin". [the ventral margin of P1 merus is actually provided with spinules (see Ngoc-Ho, 1977: 444)].

A few specimens from $S$. Java were examined that "bear four frontal teeth as in the type specimens of $U$. darwinii, whereas the P1 merus is armed with a row of denticles on the ventral margin as in $U$. hexaceras.". Therefore, " ... it seems clear that the nominal species Upogebia hexaceras (Ortmann, 1894) and U. octoceras Nobli, 1904 cannot properly be separated from $U$. darwinii Miers, 1884. Hence, the two former names should be synonymised with $U$. darwinii."

Sakai then diagnoses $U$. darwinii in such an imprecise way that several nominal species could be being described.

5) Paragebicula fallax (de Man, 1905)

In the present work, the nominal species Upogebia (Upogebia) fallax de Man, 1905 was placed in the genus Upogebia and not in Neogebicula as proposed by Sakai (1993). In Sakai (2006) however a new genus was established for this species and four others that are similar.

\section{ADDITIONAL REFERENCE}

Sakai K. (2006). Upogebiidae of the world (Decapoda Thalassinidea). Crustaceana Monographs 6. Koninklijke Brill NV, Leiden, the Netherlands: 185 pp, 24 figs. 